\title{
Emerging immunological strategies: recent advances and future directions
}

\author{
Hongyun $\mathrm{Zhao}^{2}$, Fan $\mathrm{Luo}^{3}$, Jinhui Xue ${ }^{2}, \mathrm{Su} \mathrm{Li}^{2}$, Rui-Hua Xu (凶) ${ }^{1}$ \\ ${ }^{I}$ Department of Medical Oncology, State Key Laboratory of Oncology in South China, Collaborative Innovation Center for Cancer Medicine, \\ Sun Yat-sen University Cancer Center, Guangzhou 510060, China; ${ }^{2}$ Department of Clinical Research, State Key Laboratory of Oncology in \\ South China, Collaborative Innovation Center for Cancer Medicine, Sun Yat-sen University Cancer Center, Guangzhou 510060, China; \\ ${ }^{3}$ Department of Experimental Research, State Key Laboratory of Oncology in South China, Collaborative Innovation Center for Cancer \\ Medicine, Sun Yat-sen University Cancer Center, Guangzhou 510060, China
}

(C) The Author(s) 2021. This article is published with open access at link.springer.com and journal.hep.com.cn

\begin{abstract}
Immunotherapy plays a compelling role in cancer treatment and has already made remarkable progress. However, many patients receiving immune checkpoint inhibitors fail to achieve clinical benefits, and the response rates vary among tumor types. New approaches that promote anti-tumor immunity have recently been developed, such as small molecules, bispecific antibodies, chimeric antigen receptor $T$ cell products, and cancer vaccines. Small molecule drugs include agonists and inhibitors that can reach the intracellular or extracellular targets of immune cells participating in innate or adaptive immune pathways. Bispecific antibodies, which bind two different antigens or one antigen with two different epitopes, are of great interest. Chimeric antigen receptor $T$ cell products and cancer vaccines have also been investigated. This review explores the recent progress and challenges of different forms of immunotherapy agents and provides an insight into future immunotherapeutic strategies.
\end{abstract}

Keywords cancer immunotherapy; bispecific antibodies; small molecules; chimeric antigen receptor $\mathrm{T}$ therapy; cancer vaccines

\section{Introduction}

Immunotherapy has brought tumor therapy into a new era. From surgery, to radiotherapy, chemotherapy, and targeted therapy, immuno-oncology therapy is almost within reach. However, many obstacles remain for this treatment. Although immune checkpoint inhibitors (ICIs) are now widely studied and have shown promising clinical data, many patients receiving ICIs fail to achieve clinical benefits, show varying response rates among different tumor types [1,2], and suffer from risk of immune-related adverse events (irAEs) [3].

New approaches that promote anti-tumor immunity have recently been developed, such as small molecules, bispecific antibodies (bsAbs), chimeric antigen receptor (CAR) $\mathrm{T}$ cell products, and even cancer vaccines. These new drugs can be used alone or in conjunction with

Received March 5, 2021; accepted July 31, 2021

Correspondence: Rui-Hua Xu, xurh@sysucc.org.cn existing biological antibodies and traditional therapies (radiotherapy or chemotherapy) to affect various members of the immune system and microenvironment, promote antitumor effectiveness, and benefit many patients.

This review explores the mechanisms and recent advances of small molecule drugs, bsAbs, cancer vaccines, and CAR T cell therapy. Challenges and future directions of these novel immunotherapy strategies are also discussed.

\section{Small molecules in immunotherapy}

\section{An overview}

With deepened understanding of innate immunity and tumor microenvironment (TME), many small molecules and their importance in cancer immunity have been discovered. Small molecule drugs include agonists and inhibitors that can reach the intracellular or extracellular targets of immune cells participating in specific immune pathways, enhancing anti-tumor immunity, or reducing 
immune suppression. These substances also have potential complementary or synergistic effects with existing immunotherapy. Compared with therapeutic antibodies, small molecule drugs are more permeable to tissues and the TME, and can cross the blood-brain barrier and other physiologic barriers, thus providing new options for the treatment of brain tumors and brain metastases. By adjusting the pharmacokinetic and pharmacodynamic parameters, small molecule drugs may provide the best bioavailability and avoid some of the irAEs associated with long-lasting antibody therapies. These medications also have relatively low production costs and are usually taken orally which enables easy administration.

Although a growing number of small molecules have entered early phase clinical trials, many challenges remain to be solved. Specific issues relate to understanding their mechanisms of action in the immune system and the theoretical basis for further clinical applications, as well as, the need for more safety and efficacy evaluations.

\section{Mechanisms of small molecule drugs}

Over the past decade, more than 50 small molecule drugs have been produced as single agents or in combination with monoclonal antibodies for tumor immunotherapy [4], and over 100 clinical trials are currently underway (Table 1 and Fig. S1). Small molecule agonists and inhibitors target specific pathways participating in innate or adaptive immunity through different mechanisms (Fig. 1). Understanding the mechanism of small molecule drugs and their current clinical research progress will aid in exploring their role in immunotherapy.

Table 1 Small molecules under global clinical development as of August 2020

\begin{tabular}{|c|c|c|c|c|}
\hline Small molecule & Target & Clinical studies & Phase & Cancer type \\
\hline$\overline{\mathrm{CA}-170}$ & PD-L1/VISTA & NCT02812875 & Phase 1 & Advanced solid tumors or lymphomas \\
\hline Imiquimod & TLR7 & & Approved & \\
\hline \multirow[t]{5}{*}{ Motolimod } & TLR78 & NCT02431559 & Phase $1 / 2$ & Ovarian cancer \\
\hline & & NCT03906526 & Phase 1 & Head and neck cancer \\
\hline & & NCT04272333 & Early phase 1 & Head and neck squamous cell carcinoma \\
\hline & & NCT02650635 & Phase 1 & Metastatic, persistent, recurrent, or progressive solid tumors \\
\hline & & NCT02124850 & Phase 1 & Head and neck squamous cell carcinoma \\
\hline \multirow[t]{9}{*}{ Resiquimod } & TLR7/8 & NCT00821652 & Phase 1 & Tumors \\
\hline & & NCT00948961 & Phase $1 / 2$ & Advanced malignancies \\
\hline & & NCT00960752 & Phase 2 & Melanoma \\
\hline & & NCT01204684 & Phase 2 & Brain tumors \\
\hline & & NCT01808950 & Phase $1 / 2$ & Nodular basal cell carcinoma \\
\hline & & NCT00470379 & Phase 1 & Melanoma (skin) \\
\hline & & NCT01748747 & Phase 1 & Melanoma \\
\hline & & NCT02126579 & Phase $1 / 2$ & Melanoma \\
\hline & & NCT01676831 & Phase $1 / 2$ & Cutaneous $\mathrm{T}$ cell lymphoma \\
\hline \multirow[t]{5}{*}{ VTX-2337 } & TLR8 & NCT01666444 & Phase $1 / 2$ & $\begin{array}{l}\text { Epithelial ovarian cancer, fallopian tube cancer, primary peritoneal } \\
\text { cancer }\end{array}$ \\
\hline & & NCT01334177 & Phase 1 & $\begin{array}{l}\text { Locally advanced, recurrent, or metastatic squamous cell cancer of } \\
\text { head and neck }\end{array}$ \\
\hline & & NCT03906526 & Phase 1 & Head and neck cancer \\
\hline & & NCT01836029 & Phase 2 & Head and neck squamous cell carcinoma \\
\hline & & NCT02124850 & Phase 1 & Head and neck squamous cell carcinoma \\
\hline \multirow[t]{10}{*}{ Epacadostat } & IDO1 & NCT03322540 & Phase 2 & Metastatic non-small cell lung cancer \\
\hline & & NCT03348904 & Phase 3 & Non-small cell lung cancer \\
\hline & & NCT03322566 & Phase 2 & Metastatic non-small cell lung cancer \\
\hline & & NCT02959437 & Phase $1 / 2$ & Advanced solid tumors \\
\hline & & NCT03085914 & Phase $1 / 2$ & Advanced or metastatic solid tumors \\
\hline & & NCT02318277 & Phase $1 / 2$ & Advanced solid tumors \\
\hline & & NCT03347123 & Phase $1 / 2$ & Advanced or metastatic malignancies \\
\hline & & NCT03006302 & Phase 2 & Metastatic pancreas cancer \\
\hline & & NCT03361865 & Phase 3 & Urothelial carcinoma \\
\hline & & NCT02327078 & Phase $1 / 2$ & $\begin{array}{l}\text { B cell malignancies, colorectal cancer, head and neck cancer, lung } \\
\text { cancer, lymphoma, melanoma, ovarian cancer, glioblastoma }\end{array}$ \\
\hline
\end{tabular}




\begin{tabular}{|c|c|c|c|c|}
\hline \multirow[b]{2}{*}{ Small molecule } & \multirow[b]{2}{*}{ Target } & & & \multirow[t]{2}{*}{ (Continued) } \\
\hline & & Clinical studies & Phase & \\
\hline & & NCT03374488 & Phase 3 & Recurrent or progressive metastatic urothelial carcinoma \\
\hline & & NCT03196232 & Phase 2 & Metastatic or unresectable gastresophageal junction or gastric cancer \\
\hline & & NCT03358472 & Phase 3 & Recurrent or metastatic head and neck squamous cell carcinoma \\
\hline & & NCT02364076 & Phase 2 & Thymic carcinoma \\
\hline & & NCT03493945 & Phase $1 / 2$ & $\begin{array}{l}\text { Metastatic prostate cancer, prostate cancer, prostate neoplasm, } \\
\text { advanced solid tumors, solid tumor }\end{array}$ \\
\hline & & NCT03823131 & Phase 2 & Unresectable head and neck cancer \\
\hline & & NCT03414229 & Phase 2 & Advanced sarcoma \\
\hline & & NCT03260894 & Phase 3 & Renal cell carcinoma \\
\hline & & NCT02752074 & Phase 3 & Melanoma \\
\hline & & NCT03532295 & Phase 2 & Recurrent gliomas \\
\hline \multirow{2}{*}{$\begin{array}{l}\text { Navoximod } \\
(\text { GDC-0919) }\end{array}$} & \multirow[t]{2}{*}{ IDO1 } & NCT02048709 & Phase 1 & Advanced solid tumors \\
\hline & & NCT02471846 & Phase 1 & Locally advanced or metastatic solid tumors \\
\hline \multirow[t]{10}{*}{ BMS-986205 } & \multirow[t]{10}{*}{ IDO1 } & NCT03519256 & Phase 2 & Bladder cancer \\
\hline & & NCT03792750 & Phase $1 / 2$ & Advanced malignant solid tumors \\
\hline & & NCT03192943 & Phase 1 & Advanced cancer \\
\hline & & NCT03661320 & Phase 3 & Muscle-invasive bladder cancer \\
\hline & & NCT02658890 & Phase $1 / 2$ & Advanced cancer \\
\hline & & NCT04106414 & Phase 2 & Endometrial cancer or endometrial carcinosarcoma \\
\hline & & NCT03329846 & Phase 3 & Advanced melanoma \\
\hline & & NCT03854032 & Phase 2 & Head and neck squamous cell carcinoma \\
\hline & & NCT03695250 & Phase $1 / 2$ & Liver cancer \\
\hline & & NCT04047706 & Phase 1 & Glioblastoma \\
\hline PF-06840003 & IDO1 & NCT02764151 & Phase 1 & Malignant gliomas \\
\hline \multirow{3}{*}{$\begin{array}{l}\text { CB-1158 } \\
(\text { INCB001158) }\end{array}$} & \multirow[t]{3}{*}{ ARG } & NCT03910530 & Phase 1 & Advanced solid tumors \\
\hline & & NCT02903914 & Phase $1 / 2$ & Advanced/metastatic solid tumors \\
\hline & & NCT03837509 & Phase $1 / 2$ & Multiple myeloma \\
\hline AT-38 & ARG & NCT01109004 & Phase 3 & Multiple myeloma \\
\hline \multirow[t]{2}{*}{ CB-839 } & \multirow[t]{2}{*}{ Glutaminase 1} & NCT03263429 & Phase $1 / 2$ & Ras wildtype colorectal cancer \\
\hline & & NCT02771626 & Phase $1 / 2$ & $\begin{array}{l}\text { Clear cell renal cell carcinoma, melanoma, non-small cell lung } \\
\text { cancer }\end{array}$ \\
\hline \multirow{3}{*}{$\begin{array}{l}\text { CPI-444 } \\
\text { (V81444; } \\
\text { ciforadenant) }\end{array}$} & \multirow[t]{3}{*}{ A2A receptor } & NCT02655822 & Phase 1 & Renal cell cancer, metastatic castration resistant prostate cancer \\
\hline & & NCT04280328 & Phase 1 & Multiple myeloma \\
\hline & & NCT03454451 & Phase 1 & Advanced cancers \\
\hline Preladenant & $\mathrm{A} 2 \mathrm{~A}$ receptor & NCT03099161 & Phase 1 & Advanced solid tumors \\
\hline PBF 509 & A2A receptor & NCT02403193 & Phase $1 / 2$ & Non-small cell lung cancer \\
\hline \multirow[t]{5}{*}{ AZD4635 } & \multirow[t]{5}{*}{ A2A receptor } & NCT04089553 & Phase 2 & Prostate cancer \\
\hline & & NCT04495179 & Phase 2 & Prostate cancer \\
\hline & & NCT03980821 & Phase 1 & Advanced solid malignancies \\
\hline & & NCT02740985 & Phase 1 & Advanced solid malignancies \\
\hline & & NCT03381274 & Phase $1 / 2$ & Non-small cell lung cancer \\
\hline \multirow[t]{3}{*}{ ADU-S100 } & \multirow[t]{3}{*}{ STING } & NCT03937141 & Phase 2 & Head and neck cancer \\
\hline & & NCT02675439 & Phase 1 & Advanced/metastatic solid tumors or lymphomas \\
\hline & & NCT03172936 & Phase 1 & Solid tumors and lymphomas \\
\hline \multirow[t]{2}{*}{ MK1454 } & \multirow[t]{2}{*}{ STING } & NCT03010176 & Phase 1 & Solid tumors, lymphoma \\
\hline & & NCT04220866 & Phase 2 & Head and neck squamous cell carcinoma \\
\hline \multirow{6}{*}{$\begin{array}{l}\text { Turalio } \\
\text { (pexidartinib) } \\
\text { (PLX3397) }\end{array}$} & \multirow[t]{6}{*}{ CSF1R } & NCT02777710 & Phase 1 & Metastatic/advanced pancreatic or colorectal cancers \\
\hline & & NCT02734433 & Phase 1 & Advanced solid tumors \\
\hline & & NCT01525602 & Phase 1 & Advanced solid tumors \\
\hline & & NCT02452424 & Phase $1 / 2$ & Advanced melanoma and other solid tumors \\
\hline & & NCT01349036 & Phase 2 & Recurrent glioblastoma \\
\hline & & NCT02975700 & Not applicable & Melanoma \\
\hline
\end{tabular}




\begin{tabular}{|c|c|c|c|c|}
\hline & & & & (Continued) \\
\hline \multirow[t]{2}{*}{ Small molecule } & Target & Clinical studies & Phase & Cancer type \\
\hline & & NCT01790503 & Phase $1 / 2$ & Glioblastoma \\
\hline \multirow[t]{2}{*}{ LYC-55716 } & $\mathrm{ROR} \gamma \mathrm{t}$ & NCT02929862 & Phase $1 / 2$ & Advanced or metastatic cancer \\
\hline & & NCT03396497 & Phase 1 & Non-small cell lung cancer \\
\hline \multirow[t]{2}{*}{ TNO155 } & SHP2 & NCT04000529 & Phase 1 & $\begin{array}{l}\text { Non-small cell lung carcinoma, head and neck squamous cell } \\
\text { carcinoma, esophageal SCC, gastrointestinal stromal tumors, } \\
\text { colorectal cancer }\end{array}$ \\
\hline & & NCT03114319 & Phase 1 & Advanced solid tumors \\
\hline \multirow{3}{*}{$\begin{array}{l}\text { RMC-4630 } \\
(\text { SAR442720) }\end{array}$} & SHP2 & NCT03989115 & Phase $1 / 2$ & Solid tumor \\
\hline & & NCT03634982 & Phase 1 & Relapsed/refractory solid tumors \\
\hline & & NCT04418661 & Phase 1 & Metastatic neoplasm \\
\hline \multirow[t]{2}{*}{ JAB-3068 } & SHP2 & NCT03518554 & Phase 1 & Advanced solid tumors \\
\hline & & NCT03565003 & Phase $1 / 2 \mathrm{a}$ & Advanced solid tumors \\
\hline \multirow[t]{2}{*}{ JAB-3312 } & SHP2 & NCT04121286 & Phase 1 & Advanced solid tumors \\
\hline & & NCT04045496 & Phase 1 & Advanced solid tumors \\
\hline Idelalisib & PI3K- $\delta$ & & Approved & \\
\hline \multirow[t]{5}{*}{ IPI-549 } & PI3K- $\gamma$ & NCT03961698 & Phase 2 & Breast cancer, renal cell carcinoma \\
\hline & & NCT03719326 & Phase 1 & Triple-negative breast cancer, ovarian cancer \\
\hline & & NCT02637531 & Phase 1 & Advanced solid tumors \\
\hline & & NCT03980041 & Phase 2 & Advanced urothelial carcinoma \\
\hline & & NCT03795610 & Phase 2 & Head and neck squamous cell carcinoma \\
\hline Ibrutinib & BTK & & Approved & \\
\hline $\begin{array}{l}\text { Plerixafor } \\
(\text { AMD3100) }\end{array}$ & CXCR4 & & Approved & \\
\hline \multirow[t]{5}{*}{ SX-682 } & Dual CXCR1/2 & NCT04599140 & Phase $1 / 2$ & Metastatic colorectal cancer \\
\hline & & NCT04574583 & Phase $1 / 2$ & Advanced solid tumors \\
\hline & & NCT04477343 & Phase 1 & Metastatic pancreatic ductal adenocarcinoma \\
\hline & & NCT03161431 & Phase 1 & Melanoma \\
\hline & & NCT04245397 & Phase 1 & Myelodysplastic syndromes \\
\hline \multirow[t]{3}{*}{ AZD5069 } & CXCR2 & NCT03177187 & Phase $1 / 2$ & Metastatic castration resistant prostate cancer \\
\hline & & NCT02499328 & Phase 2 & $\begin{array}{l}\text { Advanced solid tumors, metastatic head and neck squamous cell } \\
\text { carcinoma }\end{array}$ \\
\hline & & NCT02583477 & Phase $1 / 2$ & Metastatic pancreatic ductal adenocarcinoma \\
\hline \multirow[t]{3}{*}{$\mathrm{X} 4 \mathrm{P}-001$} & CXCR4 & NCT02823405 & Phase 1 & Melanoma \\
\hline & & NCT02923531 & Phase $1 / 2$ & Clear cell renal cell carcinoma \\
\hline & & NCT02667886 & Phase $1 / 2$ & Clear cell renal cell carcinoma \\
\hline \multirow[t]{2}{*}{ Maraviroc } & CCR5 & NCT01785810 & Phase 2 & Metastatic colorectal cancer \\
\hline & & NCT03274804 & Phase 1 & Colorectal cancer \\
\hline \multirow[t]{5}{*}{ BMS-813160 } & Dual CCR2/5 & NCT03184870 & Phase $1 / 2$ & Colorectal cancer, pancreatic cancer \\
\hline & & NCT04123379 & Phase 2 & Non-small cell lung cancer, hepatocellular carcinoma \\
\hline & & NCT02996110 & Phase 2 & Advanced renal cell carcinoma \\
\hline & & NCT03767582 & Phase $1 / 2$ & Locally advanced pancreatic ductal adenocarcinomas \\
\hline & & NCT03496662 & Phase $1 / 2$ & Pancreatic ductal adenocarcinoma \\
\hline FLX-475 & CCR4 & NCT03674567 & Phase $1 / 2$ & Advanced cancer \\
\hline
\end{tabular}

Data were collected from ClinicalTrials.gov. Abbreviations: PD-L1, programmed death protein-ligand 1; VISTA, V-domain Ig suppressor of T cell activation; NCT, clinicaltrials.gov identification number; TLR, toll-like receptor; IDO1, indoleamine-2,3-dioxygenase-1; ARG, arginase; A2A, Adora2a; STING, stimulator of interferon genes; CSF1R, colony stimulating factor 1 receptor; ROR $\gamma$ t, receptor-related orphan receptor gamma t; SHP2, Src homology-2containing protein tyrosine phosphatase 2; PI3K, phosphoinositide-3 kinase; BTK, Brutons tyrosine kinase; CXCR, C-X-C chemokine receptor; CCR, C-C chemokine receptor.

\section{Targeting immune checkpoints}

Programmed death protein 1 (PD-1) or programmed death protein-ligand 1 (PD-L1) antibodies have a long-half life and only act on extracellular PD-1/PD-L1, that is, they cannot penetrate the tissue barrier. Therefore, the 


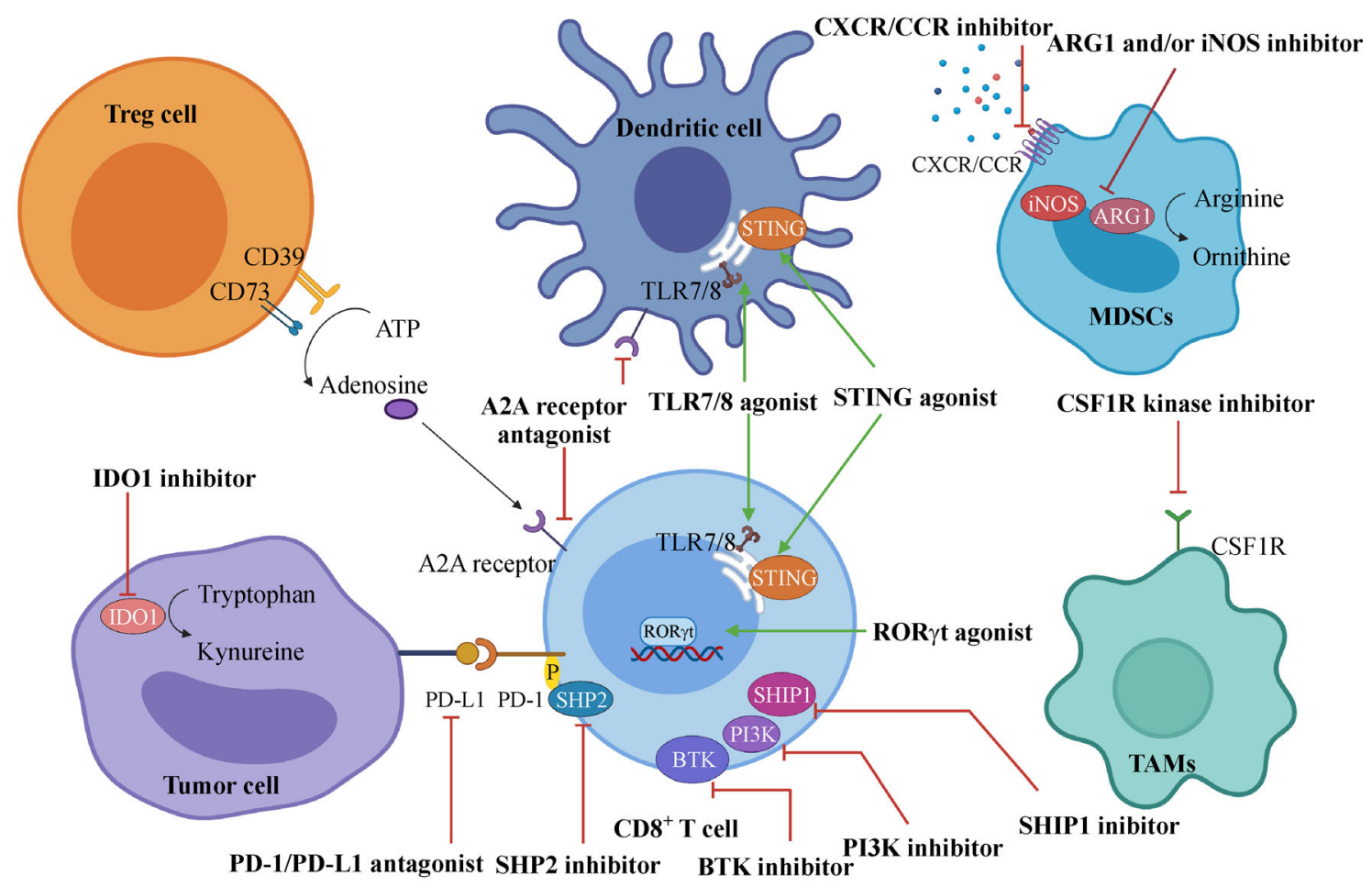

Fig. 1 Small molecule drugs and their targets in immunotherapy. This figure was created with BioRender.com. ATP, adenosine triphosphate; STING, stimulator of interferon genes; TLR, toll-like receptor; A2A, Adora2a; MDSCs, myeloid-derived suppressor cells; CXCR, C-X-C chemokine receptor; ARG1, arginase 1; IDO1, indoleamine-2,3-dioxygenase-1; PD-1, programmed death protein 1; PD-L1, programmed death protein-ligand 1; SHP2, Src homology-2-containing protein tyrosine phosphatase 2; SHIP1, SH2 domain-containing inositol-5'-phosphatase 1; PI3K, phosphoinositide-3 kinase; BTK, Brutons tyrosine kinase; ROR $\gamma \mathrm{t}$, receptor-related orphan receptor gamma t; TAMs, tumor-associated macrophages; CSF1R, colony stimulating factor 1 receptor.

occurrence of irAEs must be anticipated and monitored. The advantages of small molecules are permeabilization, oral delivery, and dose modulation, which promote the development of small molecule inhibitors acting on the PD-1/PD-L1 pathway [5-7].

Companies Bristol-Myers Squibb (BMS) and Aurigene are leading the development of small molecule PD-L1 inhibitors, with molecules such as BMS-103, BMS-142, BMS-1166, CA-327, and CA170. Small PD-L1 inhibitors developed by BMS can induce the PD-L1 dimer by filling a deep hydrophobic channel-like pocket between two PDL1 molecules and then blocking PD-1 binding [8,9]. Oral molecule, CA-327, shows anti-tumor activity in preclinical cancer models by inhibiting the PD-L1 and T cell immunoglobulin domain and mucin domain-3 (TIM-3) [10].

Developed by Aurigene, CA170 is an oral inhibitor that targets PD-L1 and the V-domain Ig suppressor of T cell activation (VISTA), and was reported as the pioneer of oral immunotherapy drugs among small molecule checkpoint inhibitors [11]. A CA-170 phase 2 clinical study is currently ongoing with data obtained from 15 non-small cell lung cancer cases and notable tumor reductions noted in six patients [12]. However, the affinity of small molecules to the target is worse than that of antibodies. Hence, off-targeting may occur and result in reduced efficacy and toxicity. Further mechanism explorations and clinical efficacy evaluations are needed. Although small molecule immune checkpoint inhibitors are mostly in preclinical and early clinical stages, these drugs will open a new avenue for tumor immunotherapy because of their pharmacokinetics and druggability advantages.

\section{Targeting innate immunity}

Pattern recognition receptors are key members in innate immunity that can distinguish pathogen-associated molecular patterns and promote $\mathrm{T}$ cell effector function [13]. Toll-like receptor (TLR) 7/8 is located in the endosome of cells. By improving the identification of foreign organisms, small molecule TLR agonists activate immune response. Imiquimod, a TLR7 agonist developed as topical cream by the Minnesota Mining \& Manufacturing Company (the United States) has been used for superficial basal cell carcinoma [14]. This drug has also shown anti-tumor activity in a phase 2 clinical trial for patients with bladder 
cancer [15]. Motolimod (VTX-2337), an agonist of TLR8, can mediate the release of IL-18 and activate natural killer (NK) cells [16]. Resiquimod (R848), a TLR7/8 agonist, helps macrophages acquire an anti-tumorigenic phenotype [17]. These TLR7/8 agonists are mostly in phase $1 / 2$ clinical trials (Table 1).

Stimulator of interferon genes (STING) participate in the innate immune recognition of immunogenic tumors [18]. The activation of the STING pathway contributes to tumor regression in mouse models [19]. STING agonists might also improve the activation of dendritic cells (DCs) and $\mathrm{T}$ cells [20]. In June of 2019, Aduro announced the results of a phase $1 \mathrm{~b}$ clinical trial for a small molecule STING antagonist (ADU-S100) combined with spartalizumab. However, only 6 out of the 83 patients with lymphoma or advanced solid tumors exhibited remarkable responses [21]. In hope of achieving relatively improved results, Aduro is currently preparing to combine ADU-S100 and Keytruda for head and neck cancers in a phase 2 clinical trial. The STING small molecule antagonist MK-1454 is also in a phase 2 clinical trial (NCT04220866).

In addition to antibodies for checkpoint modulation and cell therapy, pattern recognition receptor agonists and STING agonists provide a new approach for small molecules to prompt innate immune members to contribute to anti-tumor immune strategies. Although TLR agonists are promising targets that may exhibit synergistic effects with existing immunotherapy strategies, future research must consider that the TLR pathway is associated with gastric and pancreatic tumorigenesis [22,23]. Additional studies are required to further assess the safety of these small molecule agonists.

\section{Targeting amino acid metabolism}

The TME contains diverse immunocytes. Tumor-associated macrophages (TAMs) support tumor invasion and metastasis. Treg cells and myeloid-derived suppressor cells (MDSCs) are linked to immunosuppression in the TME. Small molecule drugs navigating metabolic pathways might strengthen the anti-tumor immunity by metabolical reprogramming of tumor and immune cells in the TME [24].

Indoleamine-2,3-dioxygenase-1 (IDO1) participates in the degradation of tryptophan to kynurenine, and selective inhibition of IDO1 enhances NK cell proliferation and reduces conversion to Treg cells [25]. BMS-986205 is one highly-efficient oral IDO1 inhibitor that can shrink bladder tumors when combined with ICIs from a phase $1 / 2$ a study [26]. IDO1 inhibitor navoximod has also shown acceptable safety and tolerance in a phase 1 clinical trial of advanced solid tumors, but its combination with atezolizumab was not beneficial [27]. A recent phase 3 trial, ECHO301, tested the efficacy of IDO1 inhibitor epacadostat combined with pembrolizumab in melanoma; however, the reaction was not better than that for pembrolizumab alone [28].

Small molecule arginase 1 (ARG1) or inducible nitric oxide synthase (iNOS) inhibitors targeting MDSCs or TAMs might overcome immunosuppression and aid the restoration of immune function [29]. ARG1 inhibitor CB1158 promotes the production of inflammatory cytokines and increases $\mathrm{CD}^{+} \mathrm{T}$ cell tumor infiltration [30]. CB-1158 is now under phase $1 / 2$ clinical trials and is also being combined with a small molecule PD-1 blockade (Table 1). Transient treatment with CB-839, an inhibitor of glutaminase 1 , also enhances cytotoxic lymphocyte-mediated antitumor responses [31].

Treatments targeting the amino acid metabolism of tumor and/or immune cells in the TME can produce a synergistic effect with existing immunotherapy approaches. However, the unexpected efficacy of IDO1 inhibitor epacadostat combined with pembrolizumab in clinical trial suggests that much efforts are need to further understand the metabolic mechanisms of immune cells to improve the effectiveness of combination therapies.

\section{Targeting adenosine signaling}

Ectonucleotidases CD73 and CD39 participate in the dephosphorylation of adenosine triphosphate to produce adenosine, which binds to the Adora2a (A2A) receptor, activates adenosine signaling, and amplifies the immunosuppressive effects of Treg cell [32]. In preclinical studies, the efficacy of ICIs have been enhanced using a combination of $\mathrm{A} 2 \mathrm{~A}$ receptor antagonists [33]. Preliminary evidence from a phase $1 \mathrm{~b}$ clinical trial showed that A2A receptor inhibitor CPI-444 combined with atuzumab exhibits disease control in refractory renal cell carcinoma [34]. Other phase $1 / 2$ studies have also assessed the safety of A2A receptor antagonists used alone or combined with ICIs in advanced tumors (Table 1). Given the immunosuppressive role of adenosine signaling in the TME, small molecule antagonists targeting A2A receptor show potential as therapeutics.

\section{Targeting cytokine signaling}

Small molecules can regulate the tumor immune response by influencing specific cytokine-mediated pathways. Retinoic acid receptor-related orphan receptor gamma $t$ (ROR $\gamma \mathrm{t}$ ) is a member of the nuclear receptor superfamily of transcription factors and plays an important role in the differentiation of cytokine interleukin-17 expressing immune cells [35]. ROR $\gamma \mathrm{t}$ agonists enhance anti-tumor immunity by activating Th17 cells and reducing Treg proliferation [36]. ROR $\gamma \mathrm{t}$ agonist, LYC-55716 in 
combination with an ICI, is currently undergoing a phase 1 clinical trial (Table 1).

Galunisertib, a transforming growth factor-beta (TGF- $\beta$ ) receptor I inhibitor, suppresses Smad family member 2 phosphorylation and was granted orphan drug designation for the treatment of liver cancer by the European Medical Agency and the FDA in the United States in 2013 [37]. Galunisertib combined with a PD-L1 blockade can enhance the expression of immune-related genes and modulate $\mathrm{T}$ cell immunity in colorectal and breast cancer mouse models [38].

Although the relationship between these cytokines and immune regulation has been established, only a few of these drugs are currently undergoing clinical trials, possibly because they mediate complex signaling pathways. Their effects on tumor cells and immune cells in the TME and the risks of combination drugs must be paid attention.

\section{Targeting oncogenic phosphatases and kinases}

Phosphatases and kinases that regulate signal transduction are potential targets for small molecule drugs. Src homology-2-containing protein tyrosine phosphatase 2 (SHP2) is involved in the downstream signaling of PD-1, which suppresses T cell function [39]. Owing to its crucial role in T cell activation, SHP2 has emerged as a treatment strategy. In colon cancer xenograft models, SHP2 inhibitor SHP099 combined with an anti-PD-1 antibody showed better reducing ability for tumor load than monotherapy [40]. The SHP2 inhibitor RMC-4630s is currently under phase $1 / 2$ clinical trials, and its pharmacokinetic profile and safety are also being evaluated (Table 1).

Colony stimulating factor 1 receptor (CSF1R) is activated by phosphorylation; pexidartinib, an oral CSF1R inhibitor, decreases TAMs and increases $\mathrm{CD} 8^{+} \mathrm{T}$ cells when used in combination with a dendritic cell cancer vaccine in mesothelioma mouse models [41]. Two clinical trials of pexidartinib monotherapy and two clinical trials of pexidartinib combined with monoclonal antibodies in advanced tumors are currently ongoing.

3- $\alpha$-Aminocholestane, a small molecule inhibitor of lipid phosphatases SH2 domain-containing inositol-5'phosphatase 1 (SHIP1), can strengthen the antitumor response of NK and T cells in mouse models [42]. IPI-549, a phosphoinositide-3 kinase (PI3K)- $\gamma$ inhibitor, can inhibit neutrophil migration and increase the antitumor efficacy of $\mathrm{CD}^{+} \mathrm{T}$ cells $[43,44]$. IPI-549 used alone or in combination with ICIs is currently under investigation (Table 1). Ibrutinib, an inhibitor of Brutons tyrosine kinase (BTK), can also enhance $T$ cell function in leukemia [45].

These small molecule drugs targeting phosphorylases and kinases usually affect tumor cell signal transduction. Additional research is needed to clarify their overall influence on tumor and immune cells prior to clinical trials.

\section{Targeting chemokine receptors}

The chemokine superfamily consists of a large number of ligands and receptors that participate in the homing, retention, circulation, and activation of immune cells [46]. C-C chemokine receptor (CCR) 2 inhibitor PF-04136309 depletes macrophages and inflammatory monocytes from the primary lesion and premetastatic liver, thereby enhancing antitumor immunity, depressing tumor growth, and reducing metastasis [47]. Inhibiting $\mathrm{C}-\mathrm{X}-\mathrm{C}$ chemokine receptor (CXCR) 4 may also reduce the accumulation of macrophages in the TME [48]. Plerixafor, a CXCR4 antagonist, has achieved good results as a chemosensitizer in phase $1 / 2$ leukemia clinical trials [49]. Other ongoing clinical trials of small molecule drugs targeting chemokine receptors have focused on CCR $2 / 5$ antagonist BMS813160, CCR4 inhibitor FLX475, and CXCR2 antagonist AZD5069 (Table 1).

The small molecule targeting of chemokine receptors is often used in combination with ICIs and chemotherapeutics in clinical trials. Given the important role of chemokines in the TME, the combinational strategies may provide meaningful clinical benefits. At present, numerous small molecule drugs have been developed to target the extracellular or intracellular pathways in adaptive or innate immunity; however, most of them are in the early stage of clinical trials. Additional basic experiments and clinical trials are urgently required to clarify their mechanism, clinical efficacy, and pharmacokinetics.

\section{Bispecific antibodies (bsAbs)}

\section{An overview}

First described in the 1960s [50], bsAbs are special molecules that can bind two antigens or one antigen with different epitopes. The technological innovation of bsAbs subsequently developed in antibody engineering and biology (Fig. 2) [51]. At present, only three bsAbs are approved for global marketing: catumaxomab (CD3/ EpCAM) [52], blinatumomab (CD3/CD19) [53], and emicizumab (FIXa/FX or Hemlibra) [54].

BsAbs are utilized in various ways, including receptoractivation, receptor-blocking, receptor-internalization, receptor-clustering, or retargeting of cytotoxic effector cells [55]. Cancer is a complicated and polyfactorial disease. Compared with monospecific monoclonal antibodies, bsAbs can synchronously bind two individual epitopes or antigens for greater impact and better treatment effects. Multi-combined regions in one antibody could help regulate diverse functional pathways in cancer, thus 


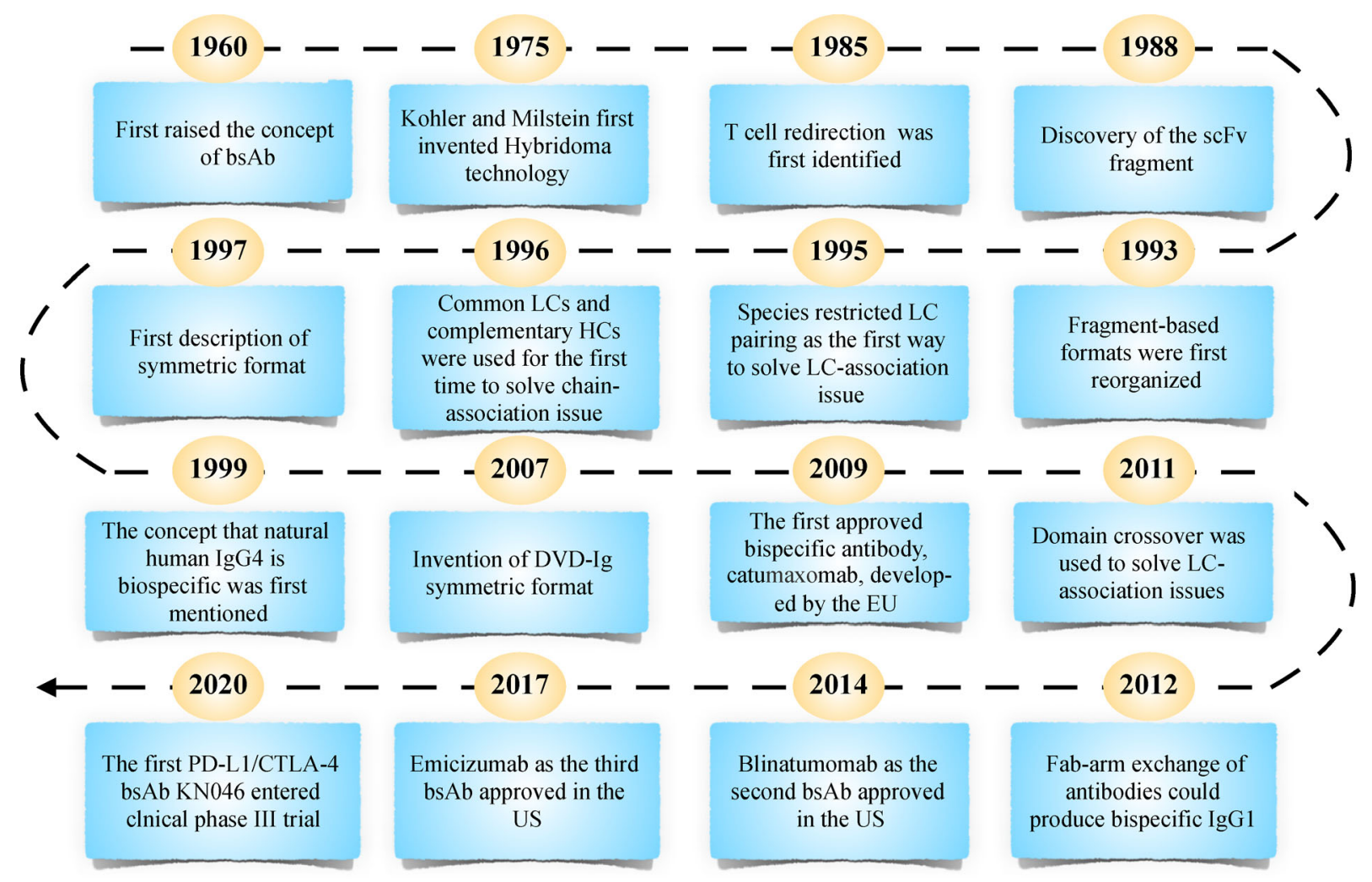

Fig. 2 Timeline of the conceptual and technical innovations contributing to the therapeutic bsAb landscape. bsAb, bispecific antibodies; DVD, dual variable domain; EU, European Union; Fab, antigen binding fragment; HC, heavy chain; Ig, immunoglobulin; LC, light chain; scFv, single-chain variable fragment.

avoiding drug resistance and decreasing the side effects on intravital tissues [56-59].

With the rapid development of gene engineering antibodies and immunology, the construction, technology platform, product research, and development of bsAbs are continuously being innovated at high speed. BsAbs are expected to be the next generation of biological therapeutics for tumors, autoimmune illness, contagious diseases, diabetes, Alzheimer's disease, and osteoporosis [51,60]. However, several challenges have been encountered during their development, namely, how to prevent poisoning and immunogenicity due to neo-antigenic determinants, how to meet the threshold for sensitizing diverse molecular mechanisms, and how to ensure the manufacturing quality [61].

\section{Preparation method of bsAbs}

BsAbs contain two different antigen binding domains that cannot be found in nature and can only be prepared artificially. Chemical coupling [62], two-hybrid method [63], and genetic engineering [64] are the most common preparation techniques for bsAbs. The most attractive application is the realization of new biological functions and therapeutic mechanism of action (MOA). However, new MOAs pose undiscovered risks that cannot be estimated in preclinical research. The indeterminacy over their safety is the major hurdle in the exploration of bsAbs. Molecular imaging studies could be used to create predictive models for the pharmacokinetic parts of bispecific constructs and to develop optimal dosing strategies [65].

\section{Structure types}

The basic structure of bsAbs consists of two pairs of heavy-light polypeptide chains connected by interchain disulfide and noncovalent bonds resembling a "Y" shape compound, including antigen binding fragments (Fabs) and a fragment crystallizable region $(\mathrm{Fc})$. BsAbs could help immune cells target tumor cells by binding to one surface antigen expressed on cancer cells and to a second antigen expressed on immune cells, such as NK cells or effector $\mathrm{T}$ cells. The fusing of the antitumor binding domain with the $\mathrm{Fc}$ receptor $(\mathrm{FcR})$ or the anti-CD3 binding domain may help produce bsAbs that can recruit immune cells. FcR is the terminal area of the antibody that interplays with the neonatal receptor, which results in 
lethal immune-mediated effects $[66,67]$.

BsAbs can be divided into two categories according to their structure: one contains the Fc region, and the other lacks the Fc region. These types can be further classified into asymmetric IgG-like bsAbs, symmetric IgG-like bsAbs, and non-IgG-like bsAbs [68]. IgG-like bsAbs can achieve effector functions, and non-IgG-like binding antibody (bAbs) are diminutive, which can improve penetration. IgG-like bAbs contain three arms/binding sites: two Fab arms and an Fc arm. The IgG-like bsAb structure promotes Fc domain-mediated effects and defends the physical properties endowed by the FcR $[69,70]$. A unique kind is asymmetric IgG-like bsAbs that possess an integrated $\mathrm{Fc}$ and a couple of distinguishing arms combining different antigens; some examples include M802, M701 [51], KN026 [71], MBS301 [72], IBI318 [73], IBI315 [74], and KN046 [75].

Symmetric IgG-like bsAbs are composed of an IgG-like $\mathrm{Fc}$ and a pair of symmetric arms formed by the association between different Fabs, single-chain variable fragment (scFV), and variable domain of heavy chain (VHH); these include EMB-01 [76], ES101 [77], K193 [78], AK104 [79], SI-B001 [80], and MGD013 [81]. Non-IgG-like bsAbs lack the $\mathrm{Fc}$ domain and exert the corresponding effect mechanism mainly through the characteristics of antigen binding; these include SHR-1701 [82], IMM0306 [83], and HX009 [84].

\section{Mechanisms of bsAbs}

BsAbs have manifold targets and special MOA.

\section{T cell redirection}

BsAbs characteristically target the antigen connected to $\mathrm{T}$ cells. By bonding to $\mathrm{T}$ cells and cancer cells, they can redirect the toxicity of effector $\mathrm{T}$ cells and obliterate cancer cells $[85,86]$.

\section{Double checkpoint inhibition}

BsAbs can block PD-1 or lymphocyte-activation gene 3 (LAG3), PD-L1, TIM-3, cytotoxic T lymphocyte-associated antigen-4 (CTLA-4), and T cell immunoreceptor with immunoglobulin and ITIM domain (TIGIT) interaction, thereby activating tumor immune response [87-90]. A number of current clinical trials are targeting the above two immune checkpoints [91-94].

\section{Co-localized blockage}

SHR-1701 can simultaneously block the PD-L1 immune checkpoint and TGF- $\beta$ on cancer cells. The aforementioned combination therapy could also increase the antineoplastic effect compared with mono-treatment in cancer cell pathways $[95,96]$.

\section{Dual signaling inhibitions}

EMB-01 (EGFR/MET) has shown promising effectiveness in numerous preclinical tests. EGFR and MET signaling paths are partly complementary and mediate the restriction of signal pathways [97-99]. SI-B001 (EGFR/HER3) activates the downstream pathways and inhibits tumorigenesis $[100,101]$.

\section{Tumor targeted immune-modulators}

Tumor-targeted immune-modulators are intended to be combined with tumor-associated antigen (TAA) and immune-regulating receptors (PD-1/CD47) to improve immune-treatment by orientating cancer cells. Such modulators include IBI315(HER2/PD-1) [74] and IMM0306 (CD47/CD20) [102].

\section{Biparatopic bsAbs (bpAbs)}

BpAbs combine two non-overlapping sites of identical antigen to cement $\mathrm{Ab}-\mathrm{Ag}$ reciprocity and enhance the cancer cellular targeting of monoclonal antibodies [103]; these include KN026 (HER2/HER2) [104] and MBS301 (HER2/HER2) [105].

\section{Research status}

Many multinational pharmaceutical companies and biotechnology companies have committed to developing bsAb-related drugs. Many Chinese companies are also involved in the research and development of bsAbs, some of which have entered the clinical or clinical application stage.

More than 100 bsAb constructions and 200 clinical trials and over 30 technology research platforms, including CrossMab (Roche), CRIBTM (China), ItabTMv (China), and FIT-IgTM (China), have been conducted over the past decade [61]. Despite starting later than other countries, Chinese bsAb development has rapidly progressed. By using the aforementioned bsAb technology research platforms, China has created 18 bsAb structures and initiated 25 clinical trials (Table 2). As of August 2020, PD-L1 and CTLA-4 are the most commonly studied targets in China [106]. In particular, $10 \mathrm{bsAb}$ and 41 clinical trials were noted for both China and other countries (Table 3) [106]. $90 \mathrm{bsAb}$ structures and 149 clinical trials are currently being studied outside of China (Table 4).

AK104 (PD-1/CTLA-4) is under a recent phase 2 multicenter study on advanced gastric adenocarcinoma. The common targeted cancer bsAb simultaneously blocks the 
Table 2 BsAbs under clinical development in China as of August 2020

\begin{tabular}{|c|c|c|c|c|}
\hline Antibody name & Targets & Clinical studies & Phase & Cancer type \\
\hline MBS-301 & HER $2 \times$ HER 2 & NCT03842085 & Phase 1 & Her2 positive recurrent or metastatic malignant solid tumor \\
\hline IBI-318 & PD-1 $\times$ PD-L1 & NCT03875157 & Phase 1 & Advanced malignancy \\
\hline IBI-322 & PD-L1 $\times$ CD47 & NCT04338659 & Phase 1 & Advanced malignancies \\
\hline IBI-315 & PD-1 $\times$ HER2 & NCT04162327 & Phase 1 & Advanced solid tumor \\
\hline \multirow[t]{2}{*}{ A-319 } & $\mathrm{CD} 3 \times \mathrm{CD} 19$ & NCT04056975 & Phase 1 & Relapsed or refractory B cell lymphoma \\
\hline & & CTR20190205 & Phase 1 & Relapsed or refractory B cell lymphoma \\
\hline M701 & $\mathrm{CD} 3 \times$ EpCAM & NCT04501744 & Phase 1 & Malignant ascites \\
\hline M802 & $\mathrm{HER} 2 \times \mathrm{CD} 3$ & NCT04501770 & Phase 1 & Her2 positive advanced solid tumor \\
\hline IMM0306 & $\mathrm{CD} 47 \times \mathrm{CD} 20$ & CTR20192612 & Phase 1 & Refractory or recurrent CD20 positive B cell non-Hodgkin's lymphoma \\
\hline KN-026 & HER $2 \times$ HER 2 & CTR20190853 & Phase 2 & Her2 positive advanced solid tumor \\
\hline EMB-01 & EGFR $\times$ c-MET & CTR20190241 & Phase 2 & Advanced or metastatic solid tumors \\
\hline \multirow[t]{3}{*}{$\mathrm{KN}-046$} & PD-L1 $\times$ CTLA-4 & NCT04469725 & Phase 2 & Thymic carcinoma \\
\hline & & NCT04474119 & Phase 3 & Non-small cell lung cancer \\
\hline & & NCT04521179 & Phase 2 & Her2 positive solid tumors \\
\hline \multirow[t]{3}{*}{ AK-104 } & PD- $1 \times$ CTLA- 4 & CTR20182027 & Phase $1 / 2$ & $\begin{array}{l}\text { Advanced solid tumor and advanced or metastatic gastric adenocarcinoma } \\
\text { or gastresophageal junction adenocarcinoma }\end{array}$ \\
\hline & & CTR20200779 & Phase 2 & Hepatocellular carcinoma \\
\hline & & CTR20202184 & Phase 2 & $\begin{array}{l}\text { Locally advanced unresectable or metastatic highly unstable satellite or } \\
\text { mismatch repair defective solid tumor, gastric carcinoma and colorectal } \\
\text { cancer }\end{array}$ \\
\hline \multirow[t]{2}{*}{ MGD-013 } & PD-1 $\times$ LAG-3 & NCT04009460 & Phase 1 & Solid tumors \\
\hline & & CTR20200549 & Phase 2 & Advanced hepatocellular carcinoma \\
\hline HX-009 & $\mathrm{PD}-1 \times \mathrm{CD} 47$ & CTR20192299 & Phase 1 & Advanced solid tumor \\
\hline M7824 & PD-L1 $\times$ TGF- $\beta$ & NCT04396886 & Phase 2 & Recurrent or metastatic carcinoma \\
\hline \multirow[t]{2}{*}{ SHR-1701 } & PD-L1 $\times$ TGF- $\beta$ & CTR20182404 & Phase 1 & Advanced solid tumor \\
\hline & & CTR20181823 & Phase 1 & Advanced solid tumor \\
\hline SI-B001 & HER3 $\times$ EGFR & CTR20200502 & Phase 1 & Locally advanced or metastatic epithelial tumors \\
\hline K193 & $\mathrm{CD} 3 \times \mathrm{CD} 19$ & CTR20191955 & Phase 1 & Refractory or recurrent B cell non-Hodgkin's lymphoma \\
\hline
\end{tabular}

Abbreviations: HER, human epidermal growth factor receptor; NCT, clinicaltrials.gov identification number; PD-1, programmed death protein 1; PD-L1, programmed death protein-ligand 1; CTR, Clinical Trial Registry; EpCAM, epithelial cell adhesion molecule; c-MET, cellular-mesenchymal epithelial transition; CTLA-4, cytotoxic T lymphocyte-associated antigen-4; LAG-3, lymphocyte-activation gene 3; TGF, transforming growth factor; EGFR, epidermal growth factor receptor.

PD-1 and CTLA-4 immune regulatory checkpoints, resulting in the potential suppression of double checkpoints and antineoplastic activity [107]. Developed by Alphamab, KN046 (PD-L1/CTLA-4) is currently in a phase 3 trial. Some studies have recently reported treatment-related toxic side effects of anti-CTLA-4 antibody $[108,109]$. Compared with each parental mAbs, KN046 can improve the safety and efficacy [110].

Developed by Biokin, SI-B001 is an anti-HER3 $\times$ anti-EGFR bsAb that is currently in a phase 1 trial and could firsthand activate the downstream paths and inhabit tumorigenesis [100,101].

BsAbs have great clinical potential because of their unique characteristics that cannot be found in monoclonal antibodies. Most bsAbs are in clinical or preclinical research. Adverse reactions, such as cytokine storms, neurotoxicity, and production processing, are the main problems for this therapy. Designing a reasonable antibody structure according to different effect mechanisms is the focus of bsAb research and development. The continued development of clinical studies and advances in upstream and downstream technology will hopefully help to solve these bsAb-related problems.

\section{Chimeric antigen receptor (CAR) T cell therapy}

CAR $T$ cells are $T$ cells designed to express an artificial receptor that redirects the $\mathrm{T}$ cell toward tumor cell antigen. CAR $T$ cell therapy is one of the most encouraging therapeutic strategies and has remarkable clinical potential. CARs are composed of four domains including the extracellular domain, the transmembrane (TM) domain, the intracellular domain, and an activation domain. The first-generation of CARs comprise an extracellular domain 
Table 3 BsAbs under clinical development in both China and other countries as of August 2020

\begin{tabular}{|c|c|c|c|c|}
\hline Antibody name & Targets & Clinical studies & Phase & Cancer type \\
\hline \multirow[t]{5}{*}{$\mathrm{KN}-026$} & \multirow[t]{5}{*}{ HER2 $\times$ HER 2} & NCT04165993 & Phase 2 & Metastatic breast cancer \\
\hline & & NCT03847168 & Phase 1 & Breast cancer \\
\hline & & NCT04040699 & Phase 1 & Her2 positive solid tumors \\
\hline & & NCT03619681 & Phase 1 & Breast cancer, gastric cancer \\
\hline & & NCT03925974 & Phase 2 & Gastric, gastresophageal junction cancer \\
\hline EMB-01 & EGFR $\times$ c-MET & NCT03797391 & Phase $1 / 2$ & Neoplasm metastasis, non-small cell lung cancer \\
\hline \multirow[t]{2}{*}{ JNJ-61186372, JNJ-6372 } & \multirow[t]{2}{*}{ EGFR $\times$ c-MET } & NCT02609776 & Phase 1 & Non-small cell lung cancer \\
\hline & & NCT04077463 & Phase 1 & Carcinoma, non-small-cell lung \\
\hline \multirow[t]{8}{*}{$\mathrm{KN}-046$} & \multirow[t]{8}{*}{ PD-L1 $\times$ CTLA-4 } & NCT04040699 & Phase 1 & Her2 positive solid tumors \\
\hline & & NCT03838848 & Phase 2 & Advanced non-small cell lung cancer \\
\hline & & NCT03927495 & Phase 2 & Esophageal squamous cell carcinoma \\
\hline & & NCT03925870 & Phase 2 & Esophageal squamous cell carcinoma \\
\hline & & NCT03733951 & Phase 1 & Advanced solid tumors \\
\hline & & NCT04054531 & Phase 2 & Non-small cell lung cancer \\
\hline & & NCT03872791 & Phase $1 / 2$ & Triple-negative breast cancer \\
\hline & & NCT03529526 & Phase 1 & Advanced solid tumors \\
\hline \multirow[t]{5}{*}{ AK-104 } & \multirow[t]{5}{*}{ PD- $1 \times$ CTLA- 4} & NCT04380805 & Phase 2 & Recurrent or metastatic cervical cancer \\
\hline & & NCT04172454 & Phase $1 / 2$ & Advanced solid tumors \\
\hline & & NCT04220307 & Phase 2 & Nasopharyngeal carcinoma \\
\hline & & NCT03261011 & Phase 1 & Advanced cancer \\
\hline & & NCT03852251 & Phase $1 / 2$ & Advanced solid tumors \\
\hline \multirow[t]{4}{*}{ MGD-013 } & \multirow[t]{4}{*}{ PD-1 $\times$ LAG-3 } & NCT04212221 & Phase $1 / 2$ & Advanced hepatocellular carcinoma \\
\hline & & NCT03219268 & Phase 1 & Advanced solid tumors \\
\hline & & NCT04178460 & Phase 1 & Gastric cancer \\
\hline & & NCT04082364 & Phase $2 / 3$ & Her2 positive gastric cancer, breast cancer \\
\hline \multirow{2}{*}{$\begin{array}{l}\text { INBRX-105-1, INBRX-105, } \\
\text { ES-101 }\end{array}$} & \multirow[t]{2}{*}{ PD-L1 $\times 4-1 B B$} & NCT03809624 & Phase 1 & Metastatic solid tumors \\
\hline & & NCT04009460 & Phase 1 & Solid tumors \\
\hline HX-009 & $\mathrm{PD}-1 \times \mathrm{CD} 47$ & NCT04097769 & Phase 1 & Advanced solid tumors \\
\hline \multirow[t]{9}{*}{ M7824 } & \multirow[t]{9}{*}{ PD-L1 $\times$ TGF- $\beta$} & NCT04246489 & Phase 2 & Uterine cervical neoplasms \\
\hline & & NCT04066491 & Phase $2 / 3$ & Biliary tract cancer \\
\hline & & NCT04396535 & Phase 2 & Advanced lung non-small cell carcinoma \\
\hline & & NCT04220775 & Phase $1 / 2$ & Recurrent head and neck squamous cell carcinoma \\
\hline & & NCT03631706 & Phase 3 & Non-small cell lung cancer \\
\hline & & NCT02517398 & Phase 1 & Solid tumors \\
\hline & & NCT03840915 & Phase $1 / 2$ & Non-small cell lung cancer \\
\hline & & NCT03840902 & Phase 2 & Non-small cell lung cancer \\
\hline & & NCT03833661 & Phase 2 & Biliary tract cancer \\
\hline \multirow[t]{4}{*}{ SHR-1701 } & \multirow[t]{4}{*}{ PD-L1 $\times$ TGF- $\beta$} & NCT03710265 & Phase 1 & Solid tumors \\
\hline & & NCT03774979 & Phase 1 & Solid tumors \\
\hline & & NCT04282070 & Phase 1 & Nasopharyngeal carcinoma \\
\hline & & NCT04324814 & Phase 1 & Advanced solid tumors \\
\hline
\end{tabular}

Abbreviations: HER, human epidermal growth factor receptor; NCT, clinicaltrials.gov identification number; EGFR, epidermal growth factor receptor; c-MET, cellular-mesenchymal epithelial transition; PD-L1, programmed death protein-ligand 1; CTLA-4, cytotoxic T lymphocyte-associated antigen-4; PD-1, programmed death protein 1; LAG-3, lymphocyte-activation gene 3; TGF, transforming growth factor.

linked to an intracellular domain without any costimulatory domain. However, no promising antitumor response was observed largely due to the lack of adequate activation [111]. As a solution, second- and thirdgeneration CARs are being developed by adding one or two co-stimulatory domains, respectively, to enhance their activity $[112,113]$.

Second-generation autologous (patient-derived) CAR T cell therapy has changed the treatment of hematologic malignancies; four CD19-targeting CARs have achieved 
Table 4 BsAbs under clinical development excluding China as of August 2020

\begin{tabular}{|c|c|c|c|c|}
\hline Antibody name & Targets & Clinical studies & Phases & Cancer type \\
\hline \multirow[t]{2}{*}{ Dilpacimab, ABT-165 } & \multirow[t]{2}{*}{ VEGF $\times$ DLL4 } & NCT01946074 & Phase 1 & Advanced solid tumors \\
\hline & & NCT03368859 & Phase 2 & Neoplasms \\
\hline \multirow[t]{3}{*}{ MP0250 } & \multirow[t]{3}{*}{$\mathrm{VEGF} \times \mathrm{HGF}$} & NCT03136653 & Phase $1 / 2$ & Relapsed multiple myeloma \\
\hline & & NCT03418532 & Phase $1 / 2$ & EGFR positive lung cancer \\
\hline & & NCT02194426 & Phase $1 / 2$ & Neoplasms \\
\hline \multirow{9}{*}{$\begin{array}{l}\text { ABL-001, NOV-1501, } \\
\text { TR-009 }\end{array}$} & \multirow[t]{9}{*}{ VEGF $\times$ DLL4 } & NCT02857868 & Phase 1 & Neoplasms \\
\hline & & NCT03595917 & Phase 1 & $\begin{array}{l}\text { Chronic myeloid leukemia, acute lymphoblastic } \\
\text { leukemia }\end{array}$ \\
\hline & & NCT03106779 & Phase 3 & Chronic myelogenous leukemia \\
\hline & & NCT04216563 & Phase 2 & $\begin{array}{l}\text { Philadelphia chromosome negative, BCR-ABL1 } \\
\text { positive chronic myelogenous leukemia }\end{array}$ \\
\hline & & NCT03292783 & Phase 1 & Advanced solid tumors \\
\hline & & NCT02081378 & Phase 1 & $\begin{array}{l}\text { Chronic myelogenous leukemia, Philadelphia } \\
\text { chromosome-positive acute lymphoblastic } \\
\text { leukemia }\end{array}$ \\
\hline & & NCT03605277 & Phase 1 & Neoplasms \\
\hline & & NCT03906292 & Phase 2 & Chronic myeloid leukemia \\
\hline & & NCT03578367 & Phase 2 & Chronic myelogenous leukemia \\
\hline \multirow{3}{*}{$\begin{array}{l}\text { Vanucizumab, } \\
\text { RG-7221 }\end{array}$} & \multirow[t]{3}{*}{ ANGPT $2 \times$ VEGF } & NCT01688206 & Phase 1 & Neoplasms \\
\hline & & NCT02141295 & Phase 2 & Colorectal cancer \\
\hline & & NCT02665416 & Phase 1 & Advanced or metastatic solid tumors \\
\hline \multirow[t]{5}{*}{ BI- 836880} & \multirow[t]{5}{*}{ ANGPT $2 \times$ VEGF } & NCT02689505 & Phase 1 & Neoplasms \\
\hline & & NCT02674152 & Phase 1 & Neoplasms \\
\hline & & NCT03972150 & Phase 1 & Neoplasms \\
\hline & & NCT03861234 & Phase 1 & Neoplasms \\
\hline & & NCT03468426 & Phase 1 & $\begin{array}{l}\text { Non-squamous, non-small-cell lung cancer, } \\
\text { neoplasms }\end{array}$ \\
\hline \multirow{3}{*}{$\begin{array}{l}\text { Navicixizumab, } \\
\text { OMP-305B83 }\end{array}$} & \multirow[t]{3}{*}{ VEGF $\times$ DLL4 } & NCT03035253 & Phase 1 & Metastatic colorectal cancer \\
\hline & & NCT03030287 & Phase 1 & Ovaries cancer, fallopian tube cancer \\
\hline & & NCT02298387 & Phase 1 & Advanced solid tumor malignancies \\
\hline \multirow[t]{4}{*}{ ZW-25 } & \multirow[t]{4}{*}{ HER $2 \times$ HER 2} & NCT04224272 & Phase 2 & Her 2 or HR positive breast cancer \\
\hline & & NCT02892123 & Phase 1 & Her2 positive cancers \\
\hline & & NCT03929666 & Phase 2 & Her2 positive gastresophageal adenocarcinoma \\
\hline & & NCT04276493 & Phase $1 / 2$ & $\begin{array}{l}\text { Breast cancer, gastric cancer, gastresophageal } \\
\text { junction cancer }\end{array}$ \\
\hline \multirow[t]{2}{*}{ MCLA-128 } & \multirow[t]{2}{*}{ HER $2 \times$ HER 3} & NCT03321981 & Phase 2 & Metastatic breast cancer \\
\hline & & NCT02912949 & Phase $1 / 2$ & Harboring NRG1 fusion solid tumors \\
\hline BCD-147 & HER2 $\times$ HER 2 & NCT03912441 & Phase 1 & Neoplasms \\
\hline BI-905677 & LRP5 $\times$ LRP6 & NCT03604445 & Phase 1 & Neoplasms \\
\hline MP0274 & HER $2 \times$ HER 2 & NCT03084926 & Phase 1 & Neoplasms \\
\hline $\begin{array}{l}\text { DuoBody-PD-L1x4-1BB, } \\
\text { GEN-1046 }\end{array}$ & PD-L1 $\times 4-1 \mathrm{BB}$ & NCT03917381 & Phase $1 / 2$ & Solid tumors \\
\hline REGN-5678 & CD28 $\times$ PSMA & NCT03972657 & Phase $1 / 2$ & Metastatic castration-resistant prostate cancer \\
\hline $\begin{array}{l}\text { FS118 mAb2, FS-118, } \\
\text { LAG-3/PD-L1 mAb2 }\end{array}$ & PD-L1 $\times$ LAG-3 & NCT03440437 & Phase 1 & Advanced cancer \\
\hline LY-3434172 & PD-1 $\times$ PD-L1 & NCT03936959 & Phase 1 & Advanced cancer \\
\hline $\mathrm{XmAb}-23104$ & PD-1 $\times$ ICOS & NCT03752398 & Phase 1 & Advanced solid tumors \\
\hline ABBV-428 & MSLN $\times$ CD40 & NCT02955251 & Phase 1 & Advanced solid tumors \\
\hline ADC-1015, ATOR-1015 & OX40 × CTLA -4 & NCT03782467 & Phase 1 & Solid tumor \\
\hline MCLA-145 & PD-L1 $\times 4-1 B B$ & NCT03922204 & Phase 1 & Advanced solid tumor, B cell lymphoma \\
\hline MEDI-5752 & PD- $1 \times$ CTLA- 4 & NCT03530397 & Phase 1 & Selected advanced solid tumors \\
\hline MGD-019 & PD- $1 \times$ CTLA- 4 & NCT03761017 & Phase 1 & Advanced solid tumor \\
\hline \multirow[t]{2}{*}{ PRS-343 } & \multirow[t]{2}{*}{ HER $2 \times 4-1 B B$} & NCT03330561 & Phase 1 & Her2 positive solid tumor \\
\hline & & NCT03650348 & Phase 1 & Her2 positive solid tumor \\
\hline
\end{tabular}




\begin{tabular}{|c|c|c|c|c|}
\hline \multirow[b]{2}{*}{ Antibody name } & \multirow[b]{2}{*}{ Targets } & \multirow[b]{2}{*}{ Clinical studies } & \multirow[b]{2}{*}{ Phases } & \multirow[t]{2}{*}{ (Continued $)$} \\
\hline & & & & \\
\hline RG-7769, RO-7121661 & PD-1 $\times$ TIM-3 & NCT03708328 & Phase 1 & Solid tumors \\
\hline $\mathrm{XmAb}-20717$ & PD- $1 \times$ CTLA- 4 & NCT03517488 & Phase 1 & Solid tumors \\
\hline $\mathrm{XmAb}-22841$ & CTLA-4 $\times$ LAG-3 & NCT03849469 & Phase 1 & Solid tumors \\
\hline MP0310 & $\mathrm{FAP} \times \mathrm{CD} 40$ & NCT04049903 & Phase 1 & Advanced solid tumor \\
\hline AK-112 & VEGF $\times$ PD-1 & NCT04047290 & Phase 1 & Neoplasms malignant \\
\hline GEN-1042 & $\mathrm{CD} 40 \times 4-1 \mathrm{BB}$ & NCT04083599 & Phase $1 / 2$ & $\begin{array}{l}\text { Solid tumor, non-small cell lung cancer, colorectal } \\
\text { cancer, melanoma }\end{array}$ \\
\hline AGEN-1423, GS-1423 & $\mathrm{CD} 73 \times$ TGF $-\beta$ & NCT03954704 & Phase 1 & Advanced solid tumors \\
\hline \multirow[t]{6}{*}{ Tebentafusp (IMCgp100) } & \multirow{6}{*}{$\begin{array}{l}\text { gp 100/HLA-A*0201 } \\
\times \text { CD3 }\end{array}$} & NCT03070392 & Phase 2 & Uveal melanoma \\
\hline & & NCT02889861 & Phase 2 & Malignant melanoma \\
\hline & & NCT02535078 & Phase $1 / 2$ & Malignant melanoma \\
\hline & & NCT01209676 & Early phase 1 & Melanoma, advanced tumors \\
\hline & & NCT02570308 & Phase $1 / 2$ & Uveal melanoma \\
\hline & & NCT01211262 & Phase 1 & Malignant melanoma \\
\hline \multirow[t]{2}{*}{ OXS-1550, DT-2219 } & \multirow[t]{2}{*}{$\mathrm{CD} 19 \times \mathrm{CD} 22$} & NCT02370160 & Phase $1 / 2$ & Refractory or relapsed B-lineage leukemia \\
\hline & & NCT00889408 & Phase 1 & Leukemia, lymphoma \\
\hline \multirow[t]{6}{*}{ AFM-13 } & \multirow[t]{6}{*}{$\mathrm{CD} 16 \times \mathrm{CD} 30$} & NCT02321592 & Phase 2 & Hodgkin lymphoma \\
\hline & & NCT01221571 & Phase 1 & Hodgkin lymphoma \\
\hline & & NCT03192202 & Phase $1 / 2$ & T cell lymphoma \\
\hline & & NCT04074746 & Phase 1 & $\begin{array}{l}\text { Recurrent anaplastic large cell lymphoma, } \\
\text { recurrent B cell non-Hodgkin lymphoma, } \\
\text { recurrent classic Hodgkin lymphoma }\end{array}$ \\
\hline & & NCT04101331 & Phase 2 & Peripheral $\mathrm{T}$ cell lymphoma \\
\hline & & NCT02665650 & Phase 1 & Hodgkin lymphoma \\
\hline \multirow{3}{*}{$\begin{array}{l}\text { Odronextamab, } \\
\text { REGN-1979 }\end{array}$} & \multirow[t]{3}{*}{$\mathrm{CD} 3 \times \mathrm{CD} 20$} & NCT02651662 & Phase 1 & Lymphoma \\
\hline & & NCT03888105 & Phase 2 & B cell non-Hodgkin lymphoma \\
\hline & & NCT02290951 & Phase 1 & $\begin{array}{l}\text { Non-Hodgkin lymphoma, chronic lymphocytic } \\
\text { leukemia }\end{array}$ \\
\hline IMC-C103C & $\begin{array}{l}\text { MAGE-A4/HLA } \\
* \text { A0201 × CD3 }\end{array}$ & NCT03973333 & Phase $1 / 2$ & Advanced solid tumors \\
\hline IMCnyeso & $\begin{array}{l}\text { NY-ESO-1/HLA } \\
* \text { A0201 } \times \text { CD } 3\end{array}$ & NCT03515551 & Phase $1 / 2$ & Advanced solid tumors \\
\hline \multirow{6}{*}{$\begin{array}{l}\text { Mosunetuzumab, } \\
\text { RG-7828 }\end{array}$} & \multirow[t]{6}{*}{$\mathrm{CD} 3 \times \mathrm{CD} 20$} & NCT03671018 & Phase $1 / 2$ & B cell non-Hodgkin lymphoma \\
\hline & & NCT04313608 & Phase 1 & B cell lymphoma \\
\hline & & NCT03677141 & Phase $1 / 2$ & B cell non-Hodgkin lymphoma \\
\hline & & NCT04246086 & Phase 1 & Follicular lymphoma \\
\hline & & NCT03677154 & Phase $1 / 2$ & Diffuse large B cell lymphoma \\
\hline & & NCT02500407 & Phase 1 & Lymphocytic leukemia \\
\hline $\begin{array}{l}\text { OXS-3550, CD161533 } \\
\text { TriKE }\end{array}$ & $\mathrm{CD} 16 \times \mathrm{CD} 33$ & NCT03214666 & Phase $1 / 2$ & Acute myelogenous leukemia, mast cell leukemia \\
\hline GEN-3013 & $\mathrm{CD} 3 \times \mathrm{CD} 20$ & NCT03625037 & Phase $1 / 2$ & Lymphoma \\
\hline MCLA-117 & $\mathrm{CD} 3 \times \mathrm{CLEC} 12$ & NCT03038230 & Phase 1 & $\begin{array}{l}\text { Acute myelogenous leukemia, acute myeloid } \\
\text { leukemia }\end{array}$ \\
\hline \multirow[t]{2}{*}{ Flotetuzumab, MGD-006 } & \multirow[t]{2}{*}{$\mathrm{CD} 3 \times \mathrm{CD} 123$} & NCT03739606 & Phase 2 & Acute and chronic myelogenous leukemia \\
\hline & & NCT04158739 & Phase 1 & Recurrent or refractory acute myeloid leukemia \\
\hline \multirow[t]{2}{*}{ MGD-007 } & \multirow[t]{2}{*}{$\mathrm{CD} 3 \times \mathrm{GPA} 33$} & NCT03531632 & Phase $1 / 2$ & Colorectal cancer metastatic \\
\hline & & NCT02248805 & Phase 1 & Colorectal carcinoma \\
\hline REGN-4018 & $\mathrm{CD} 3 \times \mathrm{MUC1} 6$ & NCT03564340 & Phase $1 / 2$ & $\begin{array}{l}\text { Recurrent ovarian cancer, recurrent fallopian tube } \\
\text { cancer, recurrent primary peritoneal cancer }\end{array}$ \\
\hline \multirow{4}{*}{$\begin{array}{l}\text { Cibisatamab, RO-6958688, } \\
\text { RG-7802 }\end{array}$} & \multirow[t]{4}{*}{$\mathrm{CD} 3 \times \mathrm{CEA}$} & NCT02650713 & Phase 1 & Solid tumors \\
\hline & & NCT02324257 & Phase 1 & Solid tumors \\
\hline & & NCT03337698 & Phase $1 / 2$ & Carcinoma, non-small-cell lung \\
\hline & & NCT03866239 & Phase 1 & Colorectal cancer \\
\hline
\end{tabular}




\begin{tabular}{|c|c|c|c|c|}
\hline & & & & (Continued) \\
\hline Antibody name & Targets & Clinical studies & Phases & Cancer type \\
\hline$\overline{\mathrm{AMG}-701}$ & $\mathrm{CD} 3 \times \mathrm{BCMA}$ & NCT03287908 & Phase 1 & Relapsed or refractory multiple myeloma \\
\hline AMG-160 & CD3 $\times$ PSMA & NCT03792841 & Phase 1 & $\begin{array}{l}\text { Metastatic castration-resistant prostate cancer, } \\
\text { prostate cancer }\end{array}$ \\
\hline AMG-330, MT-114 & $\mathrm{CD} 3 \times \mathrm{CD} 33$ & NCT02520427 & Phase 1 & Relapsed or refractory acute myeloid leukemia \\
\hline AMG-424 & $\mathrm{CD} 3 \times \mathrm{CD} 38$ & NCT03445663 & Phase 1 & Relapsed or refractory multiple myeloma \\
\hline AMG-427 & $\mathrm{CD} 3 \times \mathrm{FLT} 3$ & NCT03541369 & Phase 1 & Relapsed or refractory acute myeloid leukemia \\
\hline AMG-562 & $\mathrm{CD} 3 \times \mathrm{CD} 19$ & NCT03571828 & Phase 1 & $\begin{array}{l}\text { Diffuse large B cell lymphoma, mantle cell } \\
\text { lymphoma, follicular lymphoma }\end{array}$ \\
\hline AMG-596 & CD3 $\times$ EGFRvIII & NCT03296696 & Phase 1 & Glioblastoma or malignant glioma \\
\hline AMG-673 & $\mathrm{CD} 3 \times \mathrm{CD} 33$ & NCT03224819 & Early Phase 1 & Acute myeloid leukemia \\
\hline AMG-757 & $\mathrm{CD} 3 \times \mathrm{DLL} 3$ & NCT03319940 & Phase 1 & Small cell lung carcinoma \\
\hline \multirow[t]{3}{*}{ AMV-564, TandAb T564 } & \multirow[t]{3}{*}{$\mathrm{CD} 3 \times \mathrm{CD} 33$} & NCT03144245 & Phase 1 & Acute myeloid leukemia \\
\hline & & NCT04128423 & Phase 1 & Locally advanced or metastatic solid tumors \\
\hline & & NCT03516591 & Phase 1 & Myelodysplastic syndrome \\
\hline APVO-436 & $\mathrm{CD} 3 \times \mathrm{CD} 123$ & NCT03647800 & Phase 1 & $\begin{array}{l}\text { Acute myeloid leukemia, myelodysplastic } \\
\text { syndrome }\end{array}$ \\
\hline \multirow[t]{2}{*}{ BI-836909, AMG-420 } & \multirow[t]{2}{*}{$\mathrm{CD} 3 \times \mathrm{BCMA}$} & NCT02514239 & Phase 1 & Multiple myeloma \\
\hline & & NCT03836053 & Phase 1 & Relapsed or refractory multiple myeloma \\
\hline \multirow[t]{6}{*}{ RG-6026, RO-7082859 } & \multirow[t]{6}{*}{$\mathrm{CD} 3 \times \mathrm{CD} 20$} & NCT03533283 & Phase 1 & Non-Hodgkin's lymphoma \\
\hline & & NCT03467373 & Phase 1 & B cell lymphoma, non-Hodgkin lymphoma \\
\hline & & NCT04313608 & Phase 1 & B cell lymphoma \\
\hline & & NCT04246086 & Phase 1 & Follicular lymphoma \\
\hline & & NCT03075696 & Phase 1 & Non-Hodgkin's lymphoma \\
\hline & & NCT04077723 & Phase 1 & Lymphoma, non-Hodgkin \\
\hline EM-901, CC-93269 & $\mathrm{CD} 3 \times \mathrm{BCMA}$ & NCT03486067 & Phase 1 & Multiple myeloma \\
\hline ERY-974 & $\mathrm{CD} 3 \times \mathrm{GPC} 3$ & NCT02748837 & Phase 1 & Solid tumors \\
\hline \multirow[t]{2}{*}{ GBR-1302 } & \multirow[t]{2}{*}{$\mathrm{CD} 3 \times$ HER2 } & NCT02829372 & Phase 1 & Her2 positive solid tumors \\
\hline & & NCT03983395 & Phase $1 / 2$ & Breast cancer \\
\hline GBR-1342 & $\mathrm{CD} 3 \times \mathrm{CD} 38$ & NCT03309111 & Phase $1 / 2$ & Multiple myeloma \\
\hline GEM-333 & $\mathrm{CD} 3 \times \mathrm{CD} 33$ & NCT03516760 & Phase 1 & Acute myeloid leukemia \\
\hline GEM-3PSCA, GEM3PSCA & $\mathrm{CD} 3 \times \mathrm{PSCA}$ & NCT03927573 & Phase 1 & $\begin{array}{l}\text { Non-small cell lung cancer, breast cancer, } \\
\text { pancreatic cancer, urogenital cancer }\end{array}$ \\
\hline IGM-2323 & $\mathrm{CD} 3 \times \mathrm{CD} 20$ & NCT04082936 & Phase 1 & $\begin{array}{l}\text { Non-Hodgkin lymphoma, follicular lymphoma, } \\
\text { mantle cell lymphoma, marginal zone lymphoma }\end{array}$ \\
\hline JNJ-67571244, JNJ-1244 & $\mathrm{CD} 3 \times \mathrm{CD} 33$ & NCT03915379 & Phase 1 & Leukemia \\
\hline JNJ-63709178, JNJ-9178 & $\mathrm{CD} 3 \times \mathrm{CD} 123$ & NCT02715011 & Phase 1 & Leukemia \\
\hline JNJ-64007957, JNJ-7957 & $\mathrm{CD} 3 \times \mathrm{BCMA}$ & NCT03145181 & Phase 1 & Hematological malignancies \\
\hline JNJ-63898081, JNJ-8081 & $\mathrm{CD} 3 \times \mathrm{PSMA}$ & NCT03926013 & Phase 1 & Neoplasms \\
\hline \multirow[t]{2}{*}{ Orlotamab, MGD-009 } & \multirow[t]{2}{*}{$\mathrm{CD} 3 \times \mathrm{B} 7-\mathrm{H} 3$} & NCT03406949 & Phase 1 & Advanced solid tumors \\
\hline & & NCT02628535 & Phase 1 & Advanced solid tumors \\
\hline $\begin{array}{l}\text { Pasotuxizumab, AMG-212, } \\
\text { (BAY2010112/MT112) }\end{array}$ & $\mathrm{CD} 3 \times \mathrm{PSMA}$ & NCT01723475 & Phase 1 & Prostatic neoplasms \\
\hline PF-06671008 & $\mathrm{CD} 3 \times \mathrm{CDH} 3$ & NCT02659631 & Phase 1 & Neoplasms \\
\hline PF-06863135, PF-3135 & $\mathrm{CD} 3 \times \mathrm{BCMA}$ & NCT03269136 & Phase 1 & Multiple myeloma \\
\hline REGN-5458 & $\mathrm{CD} 3 \times \mathrm{BCMA}$ & NCT03761108 & Phase $1 / 2$ & Multiple myeloma \\
\hline RG-6194, BTRC-4017A & CD3 $\times$ HER2 & NCT03448042 & Phase 1 & Solid tumors \\
\hline TNB-383B & $\mathrm{CD} 3 \times \mathrm{BCMA}$ & NCT03933735 & Phase 1 & Multiple myeloma \\
\hline XmAb-13676, THG-338 & $\mathrm{CD} 3 \times \mathrm{CD} 20$ & NCT02924402 & Phase 1 & $\begin{array}{l}\text { B cell non-Hodgkins lymphoma, chronic } \\
\text { lymphocytic leukemia }\end{array}$ \\
\hline XmAb-14045, SQZ-622 & $\mathrm{CD} 3 \times \mathrm{CD} 123$ & NCT02730312 & Phase 1 & $\begin{array}{l}\text { Acute myelogenous leukemia, B cell acute } \\
\text { lymphoblastic leukemia, blastic plasmacytoid } \\
\text { dendritic cell neoplasm, chronic myeloid } \\
\text { leukemia }\end{array}$ \\
\hline
\end{tabular}




\begin{tabular}{|c|c|c|c|c|}
\hline & & & & (Continued) \\
\hline Antibody name & Targets & Clinical studies & Phases & Cancer type \\
\hline XmAb-18087, XENP-18087 & $\mathrm{CD} 3 \times \mathrm{SSTR} 2$ & NCT03411915 & Phase 1 & Neuroendocrine tumor, gastrointestinal neoplasm \\
\hline HPN-424 & $\mathrm{CD} 3 \times \mathrm{PSMA}$ & NCT03577028 & Phase 1 & Advanced prostate cancer \\
\hline \multirow[t]{2}{*}{ JNJ-64407564 } & $\mathrm{CD} 3 \times \mathrm{GPRC} 5 \mathrm{D}$ & NCT03399799 & Phase 1 & Hematological malignancies \\
\hline & & NCT04108195 & Phase 1 & Multiple myeloma \\
\hline RG-6160 (BFCR4350A) & $\mathrm{CD} 3 \times \mathrm{FcRH} 5$ & NCT03275103 & Phase 1 & Multiple myeloma \\
\hline NI-1701, TG-1801 & $\mathrm{CD} 19 \times \mathrm{CD} 47$ & NCT03804996 & Phase 1 & B cell lymphoma \\
\hline MCLA-158 & EGFR $\times$ LGR5 & NCT03526835 & Phase 1 & $\begin{array}{l}\text { Advanced or metastatic solid tumors, colorectal } \\
\text { cancer }\end{array}$ \\
\hline ZW-49 & HER $2 \times$ HER 2 & NCT03821233 & Phase 1 & Her2 positive cancers \\
\hline SAR-440234 & $\mathrm{CD} 3 \times \mathrm{CD} 123$ & NCT03594955 & Phase $1 / 2$ & Leukemia \\
\hline \multirow[t]{2}{*}{ AFM-11 } & $\mathrm{CD} 3 \times \mathrm{CD} 19$ & NCT02848911 & Phase 1 & Leukemia \\
\hline & & NCT02106091 & Phase 1 & $\begin{array}{l}\text { Relapsed or refractory B cell non-Hodgkin } \\
\text { lymphoma }\end{array}$ \\
\hline AFM-24 & $\mathrm{EGFR} \times \mathrm{CD} 16$ & NCT04259450 & Phase $1 / 2$ & Advanced solid tumor \\
\hline CCW-702 & $\mathrm{CD} 3 \times \mathrm{PSMA}$ & NCT04077021 & Phase 1 & Castration-resistant prostatic cancer \\
\hline HPN-217 & $\begin{array}{l}\mathrm{CD} 3 \times \\
\mathrm{BCMA}\end{array}$ & NCT04184050 & Phase $1 / 2$ & Multiple myeloma in relapse \\
\hline BI-905711 & $\begin{array}{l}\text { Cadherin-17 } \times \\
\text { TRAIL-R2 }\end{array}$ & NCT04137289 & Phase 1 & $\begin{array}{l}\text { Gastrointestinal neoplasms, cholangiocarcinoma, } \\
\text { pancreatic neoplasms }\end{array}$ \\
\hline MT110 & $\mathrm{CD} 3 \times \mathrm{EpCAM}$ & NCT00635596 & Phase 1 & Solid tumors \\
\hline
\end{tabular}

Abbreviations: VEGF, vascular endothelial growth factor; DLL4, delta like canonical notch ligand 4; NCT, clinicaltrials.gov identification number; HGF, hepatocyte growth factor; ANGPT2, angiopoietin 2; LRP, lipoprotein receptor related-protein; PSMA, prostate-specific membrane antigen; LAG-3, lymphocyte-activation gene 3; MSLN, mesothelin; TIM-3, T cell immunoglobulin domain and mucin domain-3; FAP, fibroblast activation protein; HLA, human leukocyte antigen; GPA33, glycoprotein A33; MUC16, mucin 16; BCMA, B cell maturation antigen; FLT3, FMS-liketyrosine kinease 3; EGFR, epidermal growth factor receptor; GPC3, glypican 3; PSCA, prostate stem cell antigen; CDH3, cadherin 3; SSTR2, somatostatin receptor 2; GPRC5D, Gprotein coupled receptor family C group 5 member D; LGR5, leucine-rich repeat-containing G-protein coupled receptor 5; TRAIL-R2, TNF-related apoptosisinducing ligand receptor 2; EpCAM, epithelial cell adhesion molecule.

FDA approval [114-117]. Clinical trials are also ongoing, and CAR $\mathrm{T}$ cells specific for CD30 (CD30-targeting CARs) have shown potential to treat Hodgkin's lymphoma (HL) in two phase $1 / 2$ clinical trials (NCT02690545, NCT02917083) [118]. A clinical trial of anti-CD7 universal CAR-T (U-CAR-T) cells indicated that patients with $\mathrm{T}$ cell lymphoma displayed robust CAR-T cell expansion (NCT04264078) [119]. In a phase $1 / 2$ clinical study (NCT01869166), anti-EGFR CAR-T cells were found to be a feasible therapeutic strategy for EGFRpositive patients with NSCLC [120].

However, the success of CAR T cell therapy is yet to be applied clinically. Several impediments have been encountered, namely, poor availability of tumor specific antigens, immunosuppressive characteristics of the TME, and variability in manufacturing quality and high processing costs [121-123]. The use of "off-the-shelf" allogeneic CAR $T$ cells from healthy donors could potentially overcome these issues. Allogeneic T cells are primarily derived from peripheral blood mononuclear cells, embryonic stem cells, and induced pluripotent stem cells. Allogeneic CAR $T$ products can markedly decrease the costs owing to industrialized and scaled-up production, thereby rendering CAR $\mathrm{T}$ treatment immediately accessible to a large number of patients due to the batch manufacturing of cryopreserved $\mathrm{T}$ cells. The use of allogeneic cells would also provide a high-quality product based on donor selection and allow for standardized dosing and re-dosing and a combination of CAR targets $[122,123]$. Other major issues must be addressed, including toxicities such as graft versus host disease (GVHD) and limited anti-tumor efficacy against solid tumors. Various safeguarding strategies, such as applying non- $\alpha \beta \mathrm{T}$ cells including $\gamma \delta \mathrm{T}$ cells [124], gene editing with $\alpha \beta \mathrm{T}$ cell receptor (TCR) deletion [125], and using virus-specific T cells [126] or donor-derived allogeneic T cells [127], are needed to improve the clinical safety of CAR T cell therapy. All these techniques have been designed to specifically reduce GVHD toxicity.

Although CAR T cell therapies have shown unsatisfactory efficacy in solid tumors, many promising methods can be applied for optimization. Improving CAR T structures [128] and combining with different treatment strategies such as chemotherapy [129], local therapy [130], checkpoint blockades [131], bsAbs [132], epigenetic modulators [133], vaccines [134], and oncolytic viruses [135] have all been explored to enhance the persistence and antitumor activity of CAR T cell therapy.

Despite the bumpy road ahead, the future of CAR T cell therapy looks promising because of the continuous evolution of advanced gene editing techniques and novel solutions. These innovations will help "off-the-shelf" 
allogeneic CAR $\mathrm{T}$ cell therapy to be effective, safe, and perhaps even revolutionize cancer treatment.

\section{Therapeutic cancer vaccines}

Cancer vaccines trigger immune responses against tumor cells by amplifying and broadening antigen-specific $T$ cells [136]. Tumor antigens, immune adjuvants, delivery vehicles, and formulations are the four key components of therapeutic vaccines and are vital for efficacy. Tumor antigens can be delivered in the form of genetic vaccines (DNA/RNA/viral), protein/peptide vaccines, and cell vaccines. Delivery method is also a major factor influencing vaccine efficacy [136].

Antigens for tumor vaccines include TAAs and tumorspecific antigens (TSAs). Early cancer vaccines focused on TAAs, self-antigens that have elevated levels on tumor cells but may also be expressed on normal cells. However, TAAs lacking tumor specificity increase the risk of autoimmune toxicities and have been unsuccessful in generating effective antitumor immune responses due to immune tolerance [136,137].

TSAs comprise antigens expressed by neoantigens or oncoviruses and are found exclusively in cancer cells. Neoantigen-based cancer vaccines are tumor-specific, can enhance a tumor-specific $\mathrm{T}$ cell response, and prevent toxicities caused by "off-target" damage. Recent development on bioinformatics technologies has enabled the systematic identification of tumor neoantigens; several promising studies have explored neoantigen cancer vaccines [138]. In a phase 1 clinical trial, Ott et al. reported a neoantigen vaccine that was formulated with up to 20 personized HLA-A/B-restricted peptides and has expanded neoantigen-specific $\mathrm{T}$ cells in patients with melanoma (NCT01970358) [139]. After a 4-year median follow-up of neoantigen vaccine therapy, a persistent $\mathrm{T}$ cell response was observed in patients with melanoma [140]. Neoantigen-specific $T$ cells from peripheral blood also show the potential to migrate into intracranial tumors in glioblastoma after surgical resection cases in a phase $1 \mathrm{~b}$ clinical trial (NCT02287428) [141]. These initial studies suggest that neoantigen-specific cancer vaccines are safe in patients with melanoma and glioblastoma. For further understanding on their therapeutic efficacy, in-depth studies must be conducted on the function of vaccineinduced $\mathrm{T}$ cells and the persistence of neoantigen-specific memory $\mathrm{T}$ cells.

Most therapeutic cancer vaccines are in ongoing trials, and their development can possibly enhance the efficacy of immunotherapy. In a phase $1 \mathrm{~b}$ study of a neoantigen-based peptide vaccine NEO-PV-01 in combination with a PD-1 inhibitor, epitope spreading was detected post-vaccination and correlated with improved progression free survival in patients (NCT02897765) [142]. Compared with sunitinib monotherapy, sunitinib in combination with ilixadencel, a cell-based allogeneic off-the-shelf product, exhibited a higher overall response rate in patients with synchronous metastatic renal cell carcinoma [143]. In a clinical trial of personalized tumor lysate-pulsed DCs for patients with recurrent ovarian cancer, a vaccine plus therapy seemed to improve the overall survival compared with a low-dose cyclophosphamide and bevacizumab combination therapy [144].

Although the above preliminary findings are encouraging, numerous challenges remain to be addressed. First, further discovery of personalized neoantigen targets is required to maximize their effects. Second, delivery strategies are an important factor affecting vaccine efficacy; the effectiveness of different delivery methods varies among tumor types. Finally, when a vaccine is being combined with existing treatment approaches, the timing, sequence, and dose of combination therapy must be further explored.

\section{Challenges and future direction}

New immunotherapeutic approaches provide opportunities for further drug development and bring benefits to patients. However, challenges persist during their development. Therefore, further basic and clinical research is needed.

\section{Assessment of combination therapy}

Given that anti-tumor immunity involves various steps, rational combinations to modulate different biological steps might strengthen anti-tumor responses. Effective transformation from basic discovery to clinical application could be achieved by exploring the molecular mechanisms and optimizing the strategies and timing of combination therapy to maximize its effects. The combination of four components (anti-PD1 therapy, tumor antigen-targeting antibody, interleukin-2, and a T cell vaccine) that engage in innate and adaptive immune responses was reported to eliminate large tumors in mouse model [145]. However, most drugs are in the early stages of clinical trials with complicated combinations and pose various challenges, specifically how to maximize their synergistic effects and how to avoid combinational toxicities. For a partial solution, MORPHEUS and FRACTION platforms were designed to evaluate the safety and effectiveness of combination immunotherapies in multiple phase $1 \mathrm{~b} / 2$ trials [146,147]. A novel Quick efficacy seeking trial (QuEST1) was also designed to assess different immunotherapy combinations in patients with prostate cancer [148]. The rational selection of the combination and dosage based on known molecular mechanisms to maximize their synergistic effects is yet to be elucidated. 


\section{Validated biomarkers}

Over 3000 interventional clinical trials of immunological drugs either alone or in combination are being conducted globally [149]. Nevertheless, the clinical benefits of many novel immunotherapies cannot be determined at this stage. Strategies for the identification of valid biomarkers are essential in identifying patients who will benefit the most. Many current clinical trials include the detection of serial sampling of peripheral blood or tumor specimens for the analyses of corresponding biomarkers (such as NCT01928576 and NCT03220477). In a phase 2 study of immunotherapy combinations of motolimod and doxorubicin for ovarian cancer, statistically significant differences in the overall survival of motolimod-treated patients were observed in a subgroup of patients who experienced injection site reactions; this investigation may provide biomarkers to evaluate the efficacy of combinational immunotherapies [150]. Owing to the complex interactions required for effective treatment, the development of actionable information and identifying feasible markers that can accurately classify patients is imperative.

\section{Autoimmune toxicities}

The mechanisms of immune-related toxicities must be understood to produce the best personalized treatment approach. Small changes in the molecular structures of small molecules may lead to tremendous variations in efficacy and toxicity. Diverse challenges have emerged during the exploration of bsAbs, such as reducing toxicity and immunogenicity induced by neo-epitopes, satisfying thresholds for sensitizing various molecular pathways, and assuring the quantity and quality of bsAbs.

The application of CAR T is also not without concerns. This treatment can lead to adverse effects, such as cytokine release syndrome and on-target off-tumor toxicity. Early recognition of cytokine release syndrome and aggressive steroid administration in CAR $\mathrm{T}$ treatment are important [151]. Moreover, drug-drug interactions must be considered for the toxicities of combination treatments. In a phase 2 study, the combination of pembrolizumab plus oral azacitidine CC-486 was associated with an increase in treatment-related adverse events compared with the pembrolizumab plus placebo group. This phenomenon can be attributed to the intestinal and hematological toxicities noted for the oral formulation of azacitidine [152].

\section{Improving manufacturing practices}

The production of bsAbs, CAR T cells, and neoantigenbased vaccines is expensive and time consuming. In the development of biological products, optimizing the structures and workflows according to the biological mechanisms requires special attention. Designing a reasonable antibody structure according to different effect mechanisms is the focus of current bsAb research and development.

Complete CAR T cell therapy is complex compared with autologous products; however, allogeneic CAR T products offer the advantages of industrialized production and low costs [122]. Manufacturing some biological products is also time consuming, and the production of personalized vaccines is more expensive than off-the-shelf therapeutic agents. Vaccine preparation usually takes 3-5 months at best [139]. Technological developments, such as automated flow peptide production, might help promote peptide manufacturing and decrease the production time of personalized vaccines [153]. For these emerging immunotherapy drugs, their research, development, and production time and costs must be considered.

\section{Conclusions}

Immune checkpoint therapies, such as PD-1, PD-L1, and CTLA-4 antibodies, have made considerable headway in tumor treatments for the past decade. However, only a small number of cases respond to immunotherapy and are often accompanied by adverse reactions. Therefore, new treatment options are essential to enhance immunotherapy efficacy, overcome immunosuppression, and reduce toxicity. Understanding novel immuno-oncology therapeutic strategies allow us to provide additional opportunities for patients with advanced cancer. Small molecule drugs, bsAbs, CAR-T treatment, and cancer vaccines provide appealing avenues for immunotherapy. Related preliminary preclinical and clinical studies are already underway. Cost of treatment, lack of biomarker responses, and combination therapies targeting different immune mechanisms remain as challenges to be overcome. Nevertheless, these emerging strategies can bring about new opportunities for patients with cancer.

\section{Compliance with ethics guidelines}

Hongyun Zhao, Fan Luo, Jinhui Xue, Su Li, and Rui-Hua Xu declare that they have no conflicts of interest. This manuscript is a review article and does not involve a research protocol requiring approval from relevant institutional review board or ethics committee.

Electronic Supplementary Material Supplementary material is available in the online version of this article at https://doi.org/ $10.1007 / \mathrm{s} 11684-021-0886-\mathrm{x}$ and is accessible for authorized users.

Open Access This article is licensed under a Creative Commons Attribution 4.0 International License, which permits use, sharing, adaptation, distribution and reproduction in any medium or format, 
as long as you give appropriate credit to the original author(s) and the source, provide a link to the Creative Commons license, and indicate if changes were made.

The images or other third party material in this article are included in the article's Creative Commons license, unless indicated otherwise in a credit line to the material. If material is not included in the article's Creative Commons license and your intended use is not permitted by statutory regulation or exceeds the permitted use, you will need to obtain permission directly from the copyright holder.

To view a copy of this license, visit https://creativecommons.org/ licenses/by/4.0/.

\section{References}

1. Topalian SL, Hodi FS, Brahmer JR, Gettinger SN, Smith DC, McDermott DF, Powderly JD, Carvajal RD, Sosman JA, Atkins MB, Leming PD, Spigel DR, Antonia SJ, Horn L, Drake CG, Pardoll DM, Chen L, Sharfman WH, Anders RA, Taube JM, McMiller TL, Xu H, Korman AJ, Jure-Kunkel M, Agrawal S, McDonald D, Kollia GD, Gupta A, Wigginton JM, Sznol M. Safety, activity, and immune correlates of anti-PD-1 antibody in cancer. N Engl J Med 2012; 366(26): 2443-2454

2. Skoulidis F, Goldberg ME, Greenawalt DM, Hellmann MD, Awad MM, Gainor JF, Schrock AB, Hartmaier RJ, Trabucco SE, Gay L, Ali SM, Elvin JA, Singal G, Ross JS, Fabrizio D, Szabo PM, Chang H, Sasson A, Srinivasan S, Kirov S, Szustakowski J, Vitazka P, Edwards R, Bufill JA, Sharma N, Ou SI, Peled N, Spigel DR, Rizvi H, Aguilar EJ, Carter BW, Erasmus J, Halpenny DF, Plodkowski AJ, Long NM, Nishino M, Denning WL, Galan-Cobo A, Hamdi H, Hirz T, Tong P, Wang J, Rodriguez-Canales J, Villalobos PA, Parra ER, Kalhor N, Sholl LM, Sauter JL, Jungbluth AA, Mino-Kenudson M, Azimi R, Elamin YY, Zhang J, Leonardi GC, Jiang F, Wong KK, Lee JJ, Papadimitrakopoulou VA, Wistuba II, Miller VA, Frampton GM, Wolchok JD, Shaw AT, Jänne PA, Stephens PJ, Rudin CM, Geese WJ, Albacker LA, Heymach JV. STK11/LKB1 mutations and PD-1 inhibitor resistance in KRASmutant lung adenocarcinoma. Cancer Discov 2018; 8(7): 822-835

3. Postow MA, Sidlow R, Hellmann MD. Immune-related adverse events associated with immune checkpoint blockade. N Engl J Med 2018; 378(2): 158-168

4. van der Zanden SY, Luimstra JJ, Neefjes J, Borst J, Ovaa H. Opportunities for small molecules in cancer immunotherapy. Trends Immunol 2020; 41(6): 493-511

5. Skalniak L, Zak KM, Guzik K, Magiera K, Musielak B, Pachota M, Szelazek B, Kocik J, Grudnik P, Tomala M, Krzanik S, Pyrc K, Dömling A, Dubin G, Holak TA. Small-molecule inhibitors of PD1/PD-L1 immune checkpoint alleviate the PD-L1-induced exhaustion of T-cells. Oncotarget 2017; 8(42): 72167-72181

6. Ganesan A, Ahmed M, Okoye I, Arutyunova E, Babu D, Turnbull WL, Kundu JK, Shields J, Agopsowicz KC, Xu L, Tabana Y, Srivastava N, Zhang G, Moon TC, Belovodskiy A, Hena M, Kandadai AS, Hosseini SN, Hitt M, Walker J, Smylie M, West FG, Siraki AG, Lemieux MJ, Elahi S, Nieman JA, Tyrrell DL, Houghton M, Barakat K. Comprehensive in vitro characterization of PD-L1 small molecule inhibitors. Sci Rep 2019; 9(1): 12392
7. Chen FF, Li Z, Ma D, Yu Q. Small-molecule PD-L1 inhibitor BMS1166 abrogates the function of PD-L1 by blocking its ER export. OncoImmunology 2020; 9(1): 1831153

8. Guzik K, Zak KM, Grudnik P, Magiera K, Musielak B, Törner R, Skalniak L, Dömling A, Dubin G, Holak TA. Small-molecule inhibitors of the programmed cell death-1/programmed deathligand 1 (PD-1/PD-L1) interaction via transiently induced protein states and dimerization of PD-L1. J Med Chem 2017; 60(13): $5857-5867$

9. Zak KM, Grudnik P, Guzik K, Zieba BJ, Musielak B, Dömling A, Dubin G, Holak TA. Structural basis for small molecule targeting of the programmed death ligand 1 (PD-L1). Oncotarget 2016; 7(21): 30323-30335

10. Sasikumar P, Sudarshan N, Ramachandra R, Gowda N, Samiulla D, Bilugudi P, Adurthi S, Mani J, Nair R, Ramachandra M. Preclinical efficacy in multiple syngeneic models with oral immune checkpoint antagonists targeting PD-L1 and TIM-3. Eur J Cancer 2016; 1(69): S98

11. Powderly J, Patel M, Lee J, Brody J, Meric-Bernstam F, Hamilton E, Aix SP, Garcia-Corbacho J, Bang Y, Ahn M. CA-170, a first in class oral small molecule dual inhibitor of immune checkpoints PD-L1 and VISTA, demonstrates tumor growth inhibition in preclinical models and promotes $\mathrm{T}$ cell activation in phase 1 study. Ann Oncol 2017; 28: v405-v406

12. Radhakrishnan V, Banavali S, Gupta S, Kumar A, Deshmukh C, Nag S, Beniwal S, Gopichand M, Naik R, Lakshmaiah K, Mandavia D, Ramchandra M, Prabhash K. Excellent CBR and prolonged PFS in non-squamous NSCLC with oral CA-170, an inhibitor of VISTA and PD-L1. Ann Oncol 2019; 30: v494

13. Kawai T, Akira S. The role of pattern-recognition receptors in innate immunity: update on Toll-like receptors. Nat Immunol 2010; 11(5): 373-384

14. Work Group; Invited Reviewers, Kim JYS, Kozlow JH, Mittal B, Moyer J, Olencki T, Rodgers P. Guidelines of care for the management of basal cell carcinoma. J Am Acad Dermatol 2018; 78(3): 540-559

15. Donin NM, Chamie K, Lenis AT, Pantuck AJ, Reddy M, Kivlin D, Holldack J, Pozzi R, Hakim G, Karsh LI, Lamm DL, Belkoff LH, Belldegrun AS, Holden S, Shore N. A phase 2 study of TMX-101, intravesical imiquimod, for the treatment of carcinoma in situ bladder cancer. Urol Oncol 2017; 35(2): 39.e1-39.e7

16. Dietsch GN, Lu H, Yang Y, Morishima C, Chow LQ, Disis ML, Hershberg RM. Coordinated activation of Toll-like receptor 8 (TLR8) and NLRP3 by the TLR8 agonist, VTX-2337, ignites tumoricidal natural killer cell activity. PLoS One 2016; 11(2): $\mathrm{e} 0148764$

17. Rodell CB, Arlauckas SP, Cuccarese MF, Garris CS, Li R, Ahmed MS, Kohler RH, Pittet MJ, Weissleder R. TLR7/8-agonist-loaded nanoparticles promote the polarization of tumour-associated macrophages to enhance cancer immunotherapy. Nat Biomed Eng 2018; 2(8): 578-588

18. Woo SR, Fuertes MB, Corrales L, Spranger S, Furdyna MJ, Leung MY, Duggan R, Wang Y, Barber GN, Fitzgerald KA, Alegre ML, Gajewski TF. STING-dependent cytosolic DNA sensing mediates innate immune recognition of immunogenic tumors. Immunity 2014; 41(5): 830-842

19. Corrales L, Glickman LH, McWhirter SM, Kanne DB, Sivick KE, 
Katibah GE, Woo SR, Lemmens E, Banda T, Leong JJ, Metchette K, Dubensky TW Jr, Gajewski TF. Direct activation of STING in the tumor microenvironment leads to potent and systemic tumor regression and immunity. Cell Rep 2015; 11(7): 1018-1030

20. Sivick KE, Desbien AL, Glickman LH, Reiner GL, Corrales L, Surh NH, Hudson TE, Vu UT, Francica BJ, Banda T, Katibah GE, Kanne DB, Leong JJ, Metchette K, Bruml JR, Ndubaku CO, McKenna JM, Feng Y, Zheng L, Bender SL, Cho CY, Leong ML, van Elsas A, Dubensky TW Jr, McWhirter SM. Magnitude of therapeutic STING activation determines $\mathrm{CD}^{+} \mathrm{T}$ cell-mediated anti-tumor immunity. Cell Rep 2018; 25(11): 3074-3085.e5

21. Meric-Bernstam F, Sandhu S K, Hamid O, Spreafico A, Kasper S, Dummer R, Shimizu T, Steeghs N, Lewis N, Talluto C. Phase Ib study of MIW815 (ADU-S100) in combination with spartalizumab (PDR001) in patients (pts) with advanced/metastatic solid tumors or lymphomas. J Clin Oncol 2019; 37 (15_suppl): 2507

22. Tye H, Kennedy CL, Najdovska M, McLeod L, McCormack W, Hughes N, Dev A, Sievert W, Ooi CH, Ishikawa TO, Oshima H, Bhathal PS, Parker AE, Oshima M, Tan P, Jenkins BJ. STAT3driven upregulation of TLR2 promotes gastric tumorigenesis independent of tumor inflammation. Cancer Cell 2012; 22(4): 466478

23. Ochi A, Graffeo CS, Zambirinis CP, Rehman A, Hackman M, Fallon N, Barilla RM, Henning JR, Jamal M, Rao R, Greco S, Deutsch M, Medina-Zea MV, Bin Saeed U, Ego-Osuala MO, Hajdu C, Miller G. Toll-like receptor 7 regulates pancreatic carcinogenesis in mice and humans. J Clin Invest 2012; 122(11): 4118-4129

24. Li X, Wenes M, Romero P, Huang SC, Fendt SM, Ho PC. Navigating metabolic pathways to enhance antitumour immunity and immunotherapy. Nat Rev Clin Oncol 2019; 16(7): 425-441

25. Liu X, Shin N, Koblish HK, Yang G, Wang Q, Wang K, Leffet L, Hansbury MJ, Thomas B, Rupar M, Waeltz P, Bowman KJ, Polam P, Sparks RB, Yue EW, Li Y, Wynn R, Fridman JS, Burn TC, Combs AP, Newton RC, Scherle PA. Selective inhibition of IDO1 effectively regulates mediators of antitumor immunity. Blood 2010; 115(17): 3520-3530

26. Luke J, Tabernero J, Joshua A, Desai J, Varga A, Moreno V, Gomez-Roca C, Markman B, Braud F, Patel S, Carlino M, Siu L, Curigliano G, Liu Z, Ishii Y, Wind-Rotolo M, Basciano P, Azrilevich A, Gelmon K. BMS-986205, an indoleamine 2, 3dioxygenase 1 inhibitor (IDO1i), in combination with nivolumab (nivo): updated safety across all tumor cohorts and efficacy in advanced bladder cancer (advBC). J Clin Oncol 2019; 37 (7 suppl): 358

27. Jung KH, LoRusso P, Burris H, Gordon M, Bang YJ, Hellmann MD, Cervantes A, Ochoa de Olza M, Marabelle A, Hodi FS, Ahn MJ, Emens LA, Barlesi F, Hamid O, Calvo E, McDermott D, Soliman H, Rhee I, Lin R, Pourmohamad T, Suchomel J, Tsuhako A, Morrissey K, Mahrus S, Morley R, Pirzkall A, Davis SL. Phase I study of the indoleamine 2,3-dioxygenase 1 (IDO1) inhibitor navoximod (GDC-0919) administered with PD-L1 inhibitor (atezolizumab) in advanced solid tumors. Clin Cancer Res 2019; 25(11): 3220-3228

28. Long GV, Dummer R, Hamid O, Gajewski TF, Caglevic C, Dalle S, Arance A, Carlino MS, Grob JJ, Kim TM, Demidov L, Robert C, Larkin J, Anderson JR, Maleski J, Jones M, Diede SJ, Mitchell TC. Epacadostat plus pembrolizumab versus placebo plus pembrolizumab in patients with unresectable or metastatic melanoma (ECHO-301/KEYNOTE-252): a phase 3, randomised, double-blind study. Lancet Oncol 2019; 20(8): 1083-1097

29. Adams JL, Smothers J, Srinivasan R, Hoos A. Big opportunities for small molecules in immuno-oncology. Nat Rev Drug Discov 2015; 14(9): 603-622

30. Steggerda SM, Bennett MK, Chen J, Emberley E, Huang T, Janes JR, Li W, MacKinnon AL, Makkouk A, Marguier G, Murray PJ, Neou S, Pan A, Parlati F, Rodriguez MLM, Van de Velde LA, Wang T, Works M, Zhang J, Zhang W, Gross MI. Inhibition of arginase by CB-1158 blocks myeloid cell-mediated immune suppression in the tumor microenvironment. J Immunother Cancer 2017; 5(1): 101

31. Johnson M O, Wolf M, Madden M Z, Andrejeva G, Sugiura A, Contreras D C, Maseda D, Liberti M V, Paz K, Kishton R J, Johnson M E, de Cubas A, Wu P, Li G, Zhang Y, Newcomb D C, Wells A D, Restifo N P, Rathmell W K, Locasale J W, Davila M L, Blazar B R, Rathmell J C. Distinct regulation of Th17 and Th1 cell differentiation by glutaminase-dependent metabolism. Cell 2018; 175(7): 1780-1795.e1719

32. Deaglio S, Dwyer KM, Gao W, Friedman D, Usheva A, Erat A, Chen JF, Enjyoji K, Linden J, Oukka M, Kuchroo VK, Strom TB, Robson SC. Adenosine generation catalyzed by CD39 and CD73 expressed on regulatory $\mathrm{T}$ cells mediates immune suppression. J Exp Med 2007; 204(6): 1257-1265

33. Beavis PA, Milenkovski N, Henderson MA, John LB, Allard B, Loi S, Kershaw MH, Stagg J, Darcy PK. Adenosine receptor 2A blockade increases the efficacy of anti-PD-1 through enhanced antitumor T-cell responses. Cancer Immunol Res 2015; 3(5): 506517

34. Emens L, Powderly J, Fong L, Brody J, Forde P, Hellmann M, Hughes B, Kummar S, Loi S, Luke J. CPI-444, an oral adenosine A2a receptor (A2aR) antagonist, demonstrates clinical activity in patients with advanced solid tumors. Cancer Res 2017; 77(13 suppl): CT119

35. Ivanov II, McKenzie BS, Zhou L, Tadokoro CE, Lepelley A, Lafaille JJ, Cua DJ, Littman DR. The orphan nuclear receptor ROR $\gamma t$ directs the differentiation program of proinflammatory IL$17^{+}$T helper cells. Cell 2006; 126(6): 1121-1133

36. Hu X, Liu X, Moisan J, Wang Y, Lesch CA, Spooner C, Morgan RW, Zawidzka EM, Mertz D, Bousley D, Majchrzak K, Kryczek I, Taylor C, Van Huis C, Skalitzky D, Hurd A, Aicher TD, Toogood PL, Glick GD, Paulos CM, Zou W, Carter LL. Synthetic ROR $\gamma$ agonists regulate multiple pathways to enhance antitumor immunity. OncoImmunology 2016; 5(12): e1254854

37. Herbertz S, Sawyer JS, Stauber AJ, Gueorguieva I, Driscoll KE, Estrem ST, Cleverly AL, Desaiah D, Guba SC, Benhadji KA, Slapak CA, Lahn MM. Clinical development of galunisertib (LY2157299 monohydrate), a small molecule inhibitor of transforming growth factor-beta signaling pathway. Drug Des Devel Ther 2015; 9: 4479-4499

38. Holmgaard RB, Schaer DA, Li Y, Castaneda SP, Murphy MY, Xu X, Inigo I, Dobkin J, Manro JR, Iversen PW, Surguladze D, Hall GE, Novosiadly RD, Benhadji KA, Plowman GD, Kalos M, Driscoll KE. Targeting the TGF $\beta$ pathway with galunisertib, a TGFßRI small molecule inhibitor, promotes anti-tumor immunity leading to durable, complete responses, as monotherapy and in combination with checkpoint blockade. J Immunother Cancer 
2018; 6(1): 47

39. Yokosuka T, Takamatsu M, Kobayashi-Imanishi W, HashimotoTane A, Azuma M, Saito T. Programmed cell death 1 forms negative costimulatory microclusters that directly inhibit $\mathrm{T}$ cell receptor signaling by recruiting phosphatase SHP2. J Exp Med 2012; 209(6): 1201-1217

40. Zhao M, Guo W, Wu Y, Yang C, Zhong L, Deng G, Zhu Y, Liu W, Gu Y, Lu Y, Kong L, Meng X, Xu Q, Sun Y. SHP2 inhibition triggers anti-tumor immunity and synergizes with PD-1 blockade. Acta Pharm Sin B 2019; 9(2): 304-315

41. Dammeijer F, Lievense LA, Kaijen-Lambers ME, van Nimwegen M, Bezemer K, Hegmans JP, van Hall T, Hendriks RW, Aerts JG. Depletion of tumor-associated macrophages with a CSF-1R kinase inhibitor enhances antitumor immunity and survival induced by DC immunotherapy. Cancer Immunol Res 2017; 5(7): 535-546

42. Gumbleton M, Sudan R, Fernandes S, Engelman RW, Russo CM, Chisholm JD, Kerr WG. Dual enhancement of $\mathrm{T}$ and NK cell function by pulsatile inhibition of SHIP1 improves antitumor immunity and survival. Sci Signal 2017; 10(500): eaam5353

43. Evans CA, Liu T, Lescarbeau A, Nair SJ, Grenier L, Pradeilles JA, Glenadel Q, Tibbitts T, Rowley AM, DiNitto JP, Brophy EE, O'Hearn EL, Ali JA, Winkler DG, Goldstein SI, O'Hearn P, Martin CM, Hoyt JG, Soglia JR, Cheung C, Pink MM, Proctor JL, Palombella VJ, Tremblay MR, Castro AC. Discovery of a selective phosphoinositide-3-kinase (PI3K)- $\gamma$ inhibitor (IPI-549) as an immuno-oncology clinical candidate. ACS Med Chem Lett 2016; 7(9): 862-867

44. Dwyer CJ, Arhontoulis DC, Rangel Rivera GO, Knochelmann HM, Smith AS, Wyatt MM, Rubinstein MP, Atkinson C, Thaxton JE, Neskey DM, Paulos CM. Ex vivo blockade of PI3K gamma or delta signaling enhances the antitumor potency of adoptively transferred $\mathrm{CD}^{+}{ }^{+}$T cells. Eur J Immunol 2020; 50(9): 1386-1399

45. Long M, Beckwith K, Do P, Mundy BL, Gordon A, Lehman AM, Maddocks KJ, Cheney C, Jones JA, Flynn JM, Andritsos LA, Awan F, Fraietta JA, June CH, Maus MV, Woyach JA, Caligiuri MA, Johnson AJ, Muthusamy N, Byrd JC. Ibrutinib treatment improves $\mathrm{T}$ cell number and function in CLL patients. J Clin Invest 2017; 127(8): 3052-3064

46. Zlotnik A, Yoshie O. The chemokine superfamily revisited. Immunity 2012; 36(5): 705-716

47. Sanford DE, Belt BA, Panni RZ, Mayer A, Deshpande AD, Carpenter D, Mitchem JB, Plambeck-Suess SM, Worley LA, Goetz BD, Wang-Gillam A, Eberlein TJ, Denardo DG, Goedegebuure SP, Linehan DC. Inflammatory monocyte mobilization decreases patient survival in pancreatic cancer: a role for targeting the CCL2/ CCR2 axis. Clin Cancer Res 2013; 19(13): 3404-3415

48. Chen Y, Ramjiawan RR, Reiberger T, Ng MR, Hato T, Huang Y, Ochiai H, Kitahara S, Unan EC, Reddy TP, Fan C, Huang P, Bardeesy N, Zhu AX, Jain RK, Duda DG. CXCR4 inhibition in tumor microenvironment facilitates anti-programmed death receptor-1 immunotherapy in sorafenib-treated hepatocellular carcinoma in mice. Hepatology 2015; 61(5): 1591-1602

49. Uy GL, Rettig MP, Motabi IH, McFarland K, Trinkaus KM, Hladnik LM, Kulkarni S, Abboud CN, Cashen AF, StockerlGoldstein KE, Vij R, Westervelt P, DiPersio JF. A phase 1/2 study of chemosensitization with the CXCR4 antagonist plerixafor in relapsed or refractory acute myeloid leukemia. Blood 2012; 119
(17): $3917-3924$

50. Nisonoff A, Wissler FC, Lipman LN. Properties of the major component of a peptic digest of rabbit antibody. Science 1960; 132 (3441): 1770-1771

51. Labrijn AF, Janmaat ML, Reichert JM, Parren PWHI. Bispecific antibodies: a mechanistic review of the pipeline. Nat Rev Drug Discov 2019; 18(8): 585-608

52. Chelius D, Ruf P, Gruber P, Plöscher M, Liedtke R, Gansberger E, Hess J, Wasiliu M, Lindhofer $\mathrm{H}$. Structural and functional characterization of the trifunctional antibody catumaxomab. MAbs 2010; 2(3): 309-319

53. Klinger M, Brandl C, Zugmaier G, Hijazi Y, Bargou RC, Topp MS, Gökbuget N, Neumann S, Goebeler M, Viardot A, Stelljes M, Brüggemann M, Hoelzer D, Degenhard E, Nagorsen D, Baeuerle PA, Wolf A, Kufer P. Immunopharmacologic response of patients with B-lineage acute lymphoblastic leukemia to continuous infusion of T cell-engaging CD19/CD3-bispecific BiTE antibody blinatumomab. Blood 2012; 119(26): 6226-6233

54. Kitazawa T, Esaki K, Tachibana T, Ishii S, Soeda T, Muto A, Kawabe Y, Igawa T, Tsunoda H, Nogami K, Shima M, Hattori K. Factor VIIIa-mimetic cofactor activity of a bispecific antibody to factors IX/IXa and X/Xa, emicizumab, depends on its ability to bridge the antigens. Thromb Haemost 2017; 117(7): 1348-1357

55. Dickopf S, Georges GJ, Brinkmann U. Format and geometries matter: structure-based design defines the functionality of bispecific antibodies. Comput Struct Biotechnol J 2020; 18: $1221-1227$

56. Mazor Y, Hansen A, Yang C, Chowdhury PS, Wang J, Stephens G, $\mathrm{Wu} \mathrm{H}$, Dall'Acqua WF. Insights into the molecular basis of a bispecific antibody's target selectivity. MAbs 2015; 7(3): 461-469

57. Mazor Y, Sachsenmeier KF, Yang C, Hansen A, Filderman J, Mulgrew K, Wu H, Dall'Acqua WF. Enhanced tumor-targeting selectivity by modulating bispecific antibody binding affinity and format valence. Sci Rep 2017; 7(1): 40098

58. Lopez-Albaitero A, Xu H, Guo H, Wang L, Wu Z, Tran H, Chandarlapaty S, Scaltriti M, Janjigian Y, de Stanchina E, Cheung NK. Overcoming resistance to HER2-targeted therapy with a novel HER2/CD3 bispecific antibody. OncoImmunology 2017; 6(3): e1267891

59. Moores SL, Chiu ML, Bushey BS, Chevalier K, Luistro L, Dorn K, Brezski RJ, Haytko P, Kelly T, Wu SJ, Martin PL, Neijssen J, Parren PW, Schuurman J, Attar RM, Laquerre S, Lorenzi MV, Anderson GM. A novel bispecific antibody targeting EGFR and cMet is effective against EGFR inhibitor-resistant lung tumors. Cancer Res 2016; 76(13): 3942-3953

60. Thakur A, Huang M, Lum LG. Bispecific antibody based therapeutics: strengths and challenges. Blood Rev 2018; 32(4): 339-347

61. Zhang MY, Lu JJ, Wang L, Gao ZC, Hu H, Ung CO, Wang YT. Development of monoclonal antibodies in China: overview and prospects. BioMed Res Int 2015; 2015: 168935

62. Staerz UD, Kanagawa O, Bevan MJ. Hybrid antibodies can target sites for attack by T cells. Nature 1985; 314(6012): 628-631

63. Staerz UD, Bevan MJ. Hybrid hybridoma producing a bispecific monoclonal antibody that can focus effector T-cell activity. Proc Natl Acad Sci USA 1986; 83(5): 1453-1457

64. Kontermann RE. Dual targeting strategies with bispecific anti- 
bodies. MAbs 2012; 4(2): 182-197

65. Nie S, Wang Z, Moscoso-Castro M, D’Souza P, Lei C, Xu J, Gu J. Biology drives the discovery of bispecific antibodies as innovative therapeutics. Antib Ther 2020; 3(1): 18-62

66. Grugan KD, Dorn K, Jarantow SW, Bushey BS, Pardinas JR, Laquerre S, Moores SL, Chiu ML. Fc-mediated activity of EGFR x c-Met bispecific antibody JNJ-61186372 enhanced killing of lung cancer cells. MAbs 2017; 9(1): 114-126

67. Wang Q, Chung CY, Chough S, Betenbaugh MJ. Antibody glycoengineering strategies in mammalian cells. Biotechnol Bioeng 2018; 115(6): 1378-1393

68. Kontermann RE, Brinkmann U. Bispecific antibodies. Drug Discov Today 2015; 20(7): 838-847

69. Gupta A, Kumar Y. Bispecific antibodies: a novel approach for targeting prominent biomarkers. Hum Vaccin Immunother 2020; 16(11): 2831-2839

70. Kontermann RE, Brinkmann U. Bispecific antibodies. Drug Discov Today 2015; 20(7): 838-847

71. Xu T, Tau X, Wang X, Li Q, Minjie P, Zhang H, Han L, Zhang Q. Patent US 10808043 (B2); PCT/CN2016/070447. 2020

72. Li F, Zhang B, Ye P, Zhao J, Huang S, Jin C. Patent US 9745382 (B1); PCT/CN2017/093816, 2017

73. Liu J, Song N, Yang Y, Jin M. Patent WO2018177324 (A1); PCT/ CN2018/080858. 2018

74. Liu J, Song N, Yang Y. Patent WO2018090950 (A1); PCT/ CN2017/111310. 2018

75. Xu T, Dong Y, Wang P. Patent US 20180291103 (A1); PCT/ CN2016/092679. 2017

76. Wu C. Patent US 10266608 (B2); PCT/US2014/072336. 2019

77. Eckelman B, Timmer JC, Hata C, Jones KS, Hussain A, Razai AS, Becklund B, Pandit R, Kaplan M, Rason L, Deveraux Q, Eckelman BP, Timmer JC, Hata C, Jones KS, Hussain A, Razai AS, Becklund B, Pandit R, Kaplan M, Rascon L, Deveraux Q. Patent US 20170198050 (A1); PCT/US2017/013040. 2017

78. Kong J, Ye Y, Zhou P, Huang Y, Kong Q, Yang S, Xu L, Zhang K, Zhang K, Wang S. Patent US 20190284279 (A1); PCT/CN2018/ 085397. 2019

79. Li B, Xia Y, Wang ZM, Zhang P. Patent US 20190185569 (A1); PCT/CN2017/098466. 2019

80. Gao Z, TAN P, Kovacevich B, Renshaw B, Adamo J, Mak SA, Zhuo S, Chen L. Patent WO2016106157 (A1); PCT/US2015/ 066951. 2015

81. LaMotte-Mohs R, Shah K, Smith D, Gorlatov S, Ciccarone V, Tamura J, Li H, Rillema J, Licea M. MGD013, a bispecific PD-1 X LAG-3 dual affinity re-targeting $\left(\mathrm{DART}^{\mathrm{s}}\right.$ ) protein with T-cell immunomodulatory activity for cancer treatment. Cancer Res 2016; 76 (14 Supplement): 3217-3217

82. Gu J, Luo X, Tao W. Patent CN 201880004344.6A; PCT/CN2018/ 086451. 2018

83. Tian W, Li S. Patent WO201816650; PCT/CN2018/079187. 2018

84. Huang Y, Zhang F, Xi G. Patent WO2019109357; PCT/CN2017/ 115323. 2019

85. Hinner MJ, Aiba RSB, Wiedenmann A, Schlosser C, Allersdorfer A, Matschiner G, Rothe C, Moebius U, Kohrt HE, Olwill SA. Costimulatory $\mathrm{T}$ cell engagement via a novel bispecific antiCD137/anti-HER2 protein. J Immunother Cancer 2015; 3(Suppl 2): 187
86. Chames P, Baty D. Bispecific antibodies for cancer therapy. Curr Opin Drug Discov Devel 2009; 12(2): 276-283

87. Poole RM. Pembrolizumab: first global approval. Drugs 2014; 74 (16): 1973-1981

88. Markham A. Atezolizumab: first global approval. Drugs 2016; 76 (12): 1227-1232

89. Kim ES. Avelumab: first global approval. Drugs 2017; 77(8): 929 937

90. Syed YY. Durvalumab: first global approval. Drugs 2017; 77(12): 1369-1376

91. Osipov A, Zaidi N, Laheru DA. Dual checkpoint inhibition in pancreatic cancer: revealing the limitations of synergy and the potential of novel combinations. JAMA Oncol 2019; 5(10): 14381439

92. Reck M, Borghaei H, O'Byrne KJ. Nivolumab plus ipilimumab in non-small-cell lung cancer. Future Oncol 2019; 15(19): 2287-2302

93. Winer A, Ghatalia P, Bubes N, Anari F, Varshavsky A, Kasireddy V, Liu Y, El-Deiry WS. Dual checkpoint inhibition with ipilimumab plus nivolumab after progression on sequential PD-1/ PDL-1 inhibitors pembrolizumab and atezolizumab in a patient with Lynch syndrome, metastatic colon, and localized urothelial cancer. Oncologist 2019; 24(11): 1416-1419

94. Hassel JC, Heinzerling L, Aberle J, Bähr O, Eigentler TK, Grimm MO, Grünwald V, Leipe J, Reinmuth N, Tietze JK, Trojan J, Zimmer L, Gutzmer R. Combined immune checkpoint blockade (anti-PD-1/anti-CTLA-4): evaluation and management of adverse drug reactions. Cancer Treat Rev 2017; 57: 36-49

95. Topalian SL, Drake CG, Pardoll DM. Targeting the PD-1/B7-H1 (PD-L1) pathway to activate anti-tumor immunity. Curr Opin Immunol 2012; 24(2): 207-212

96. Hugo W, Zaretsky JM, Sun L, Song C, Moreno BH, Hu-Lieskovan S, Berent-Maoz B, Pang J, Chmielowski B, Cherry G, Seja E, Lomeli S, Kong X, Kelley MC, Sosman JA, Johnson DB, Ribas A, Lo RS. Genomic and transcriptomic features of response to antiPD-1 therapy in metastatic melanoma. Cell 2016; 165(1): 35-44

97. Engelman JA, Zejnullahu K, Mitsudomi T, Song Y, Hyland C, Park JO, Lindeman N, Gale CM, Zhao X, Christensen J, Kosaka T, Holmes AJ, Rogers AM, Cappuzzo F, Mok T, Lee C, Johnson BE, Cantley LC, Jänne PA. MET amplification leads to gefitinib resistance in lung cancer by activating ERBB3 signaling. Science 2007; 316(5827): 1039-1043

98. Turke AB, Zejnullahu K, Wu YL, Song Y, Dias-Santagata D, Lifshits E, Toschi L, Rogers A, Mok T, Sequist L, Lindeman NI, Murphy C, Akhavanfard S, Yeap BY, Xiao Y, Capelletti M, Iafrate AJ, Lee C, Christensen JG, Engelman JA, Jänne PA. Preexistence and clonal selection of MET amplification in EGFR mutant NSCLC. Cancer Cell 2010; 17(1): 77-88

99. Yano S, Yamada T, Takeuchi S, Tachibana K, Minami Y, Yatabe Y, Mitsudomi T, Tanaka H, Kimura T, Kudoh S, Nokihara H, Ohe Y, Yokota J, Uramoto H, Yasumoto K, Kiura K, Higashiyama M, Oda M, Saito H, Yoshida J, Kondoh K, Noguchi M. Hepatocyte growth factor expression in EGFR mutant lung cancer with intrinsic and acquired resistance to tyrosine kinase inhibitors in a Japanese cohort. J Thorac Oncol 2011; 6(12): 2011-2017

100. van Lengerich B, Agnew C, Puchner EM, Huang B, Jura N. EGF and NRG induce phosphorylation of HER3/ERBB3 by EGFR using distinct oligomeric mechanisms. Proc Natl Acad Sci USA 
2017; 114(14): E2836-E2845

101. Mujoo K, Choi BK, Huang Z, Zhang N, An Z. Regulation of ERBB3/HER3 signaling in cancer. Oncotarget 2014; 5(21): 10222-10236

102. Tian W, Li S, Chen D, Liang G, Zhang L, Zhang W, Tu X, Peng L, Weng J, Zhao G. Preclinical development of a bispecific antibodytrap selectively targeting CD47 and CD20 for the treatment of B cell lineage cancer. Cancer Res 2019; 79(13 Suppl): Abstract nr 545

103. Robert B, Dorvillius M, Buchegger F, Garambois V, Mani JC, Pugnières M, Mach JP, Pèlegrin A. Tumor targeting with newly designed biparatopic antibodies directed against two different epitopes of the carcinoembryonic antigen (CEA). Int J Cancer 1999; 81(2): 285-291

104. Wei H, Cai H, Jin Y, Wang P, Zhang Q, Lin Y, Wang W, Cheng J, Zeng N, Xu T, Zhou A. Structural basis of a novel heterodimeric Fc for bispecific antibody production. Oncotarget 2017; 8(31): 51037-51049

105. Li F, Zhang B, Ye P, Zhao J, Huang S, Jin C. Bispecific anti-HER2 antibody. Patent US 9745382 (B1); PCT/CN2017/093816. 2017

106. Center for Drug Evaluation of the National Medical Products Authority. http://www.cde.org.cn/ (accessed August 31, 2020)

107. Li B, Xia Y, Wang Z M, Zhang P. Patent MX2019002254 (A). 2019

108. Du X, Liu M, Su J, Zhang P, Tang F, Ye P, Devenport M, Wang X, Zhang Y, Liu Y, Zheng P. Uncoupling therapeutic from immunotherapy-related adverse effects for safer and effective anti-CTLA-4 antibodies in CTLA4 humanized mice. Cell Res 2018; 28(4): 433-447

109. Du X, Tang F, Liu M, Su J, Zhang Y, Wu W, Devenport M, Lazarski CA, Zhang P, Wang X, Ye P, Wang C, Hwang E, Zhu T, $\mathrm{Xu}$ T, Zheng P, Liu Y. A reappraisal of CTLA-4 checkpoint blockade in cancer immunotherapy. Cell Res 2018; 28(4): 416-432

110. Liu Y, Zheng P. Preserving the CTLA-4 checkpoint for safer and more effective cancer immunotherapy. Trends Pharmacol Sci 2020; 41(1): 4-12

111. Duell J, Lurati S, Dittrich M, Bedke T, Pule M, Einsele H, Rossig C, Topp M S. First generation chimeric antigen receptor display functional defects in key signal pathways upon antigen stimulation. Blood 2010; 116(21): 2088

112. Carpenito C, Milone MC, Hassan R, Simonet JC, Lakhal M, Suhoski MM, Varela-Rohena A, Haines KM, Heitjan DF, Albelda SM, Carroll RG, Riley JL, Pastan I, June CH. Control of large, established tumor xenografts with genetically retargeted human $\mathrm{T}$ cells containing CD28 and CD137 domains. Proc Natl Acad Sci USA 2009; 106(9): 3360-3365

113. June CH, O’Connor RS, Kawalekar OU, Ghassemi S, Milone MC. CAR T cell immunotherapy for human cancer. Science 2018; 359 (6382): 1361-1365

114. Prasad V. Tisagenlecleucel - the first approved CAR-T-cell therapy: implications for payers and policy makers. Nat Rev Clin Oncol 2018; 15(1): 11-12

115. Bouchkouj N, Kasamon YL, de Claro RA, George B, Lin X, Lee S, Blumenthal GM, Bryan W, McKee AE, Pazdur R. FDA approval summary: axicabtagene ciloleucel for relapsed or refractory large B-cell lymphoma. Clin Cancer Res 2019; 25(6): 1702-1708

116. Voelker R. CAR-T therapy is approved for mantle cell lymphoma.
JAMA 2020; 324(9): 832

117. Mullard A. FDA approves fourth CAR-T cell therapy. Nat Rev Drug Discov 2021; 20(3): 166

118. Ramos CA, Grover NS, Beaven AW, Lulla PD, Wu MF, Ivanova A, Wang T, Shea TC, Rooney CM, Dittus C, Park SI, Gee AP, Eldridge PW, McKay KL, Mehta B, Cheng CJ, Buchanan FB, Grilley BJ, Morrison K, Brenner MK, Serody JS, Dotti G, Heslop HE, Savoldo B. Anti-CD30 CAR-T cell therapy in relapsed and refractory Hodgkin lymphoma. J Clin Oncol 2020; 38(32): 37943804

119. Huang R, Li X, He Y, Zhu W, Gao L, Liu Y, Gao L, Wen Q, Zhong JF, Zhang C, Zhang X. Recent advances in CAR-T cell engineering. J Hematol Oncol 2020; 13(1): 86

120. Liu Y, Guo Y, Wu Z, Feng K, Tong C, Wang Y, Dai H, Shi F, Yang Q, Han W. Anti-EGFR chimeric antigen receptor-modified T cells in metastatic pancreatic carcinoma: a phase I clinical trial. Cytotherapy 2020; 22(10): 573-580

121. Cutmore LC, Brown NF, Raj D, Chauduri S, Wang P, Maher J, Wang Y, Lemoine NR, Marshall JF. Pancreatic Cancer UK Grand Challenge: developments and challenges for effective CAR T cell therapy for pancreatic ductal adenocarcinoma. Pancreatology 2020; 20(3): 394-408

122. Depil S, Duchateau P, Grupp SA, Mufti G, Poirot L. 'Off-the-shelf' allogeneic CAR T cells: development and challenges. Nat Rev Drug Discov 2020; 19(3): 185-199

123. Cutmore LC, Marshall JF. Current perspectives on the use of off the shelf CAR-T/NK cells for the treatment of cancer. Cancers (Basel) 2021; 13(8): 1926

124. Capsomidis A, Benthall G, Van Acker HH, Fisher J, Kramer AM, Abeln Z, Majani Y, Gileadi T, Wallace R, Gustafsson K, Flutter B, Anderson J. Chimeric antigen receptor-engineered human gamma delta $\mathrm{T}$ cells: enhanced cytotoxicity with retention of cross presentation. Mol Ther 2018; 26(2): 354-365

125. Torikai H, Reik A, Liu PQ, Zhou Y, Zhang L, Maiti S, Huls H, Miller JC, Kebriaei P, Rabinovich B, Lee DA, Champlin RE, Bonini C, Naldini L, Rebar EJ, Gregory PD, Holmes MC, Cooper LJ. A foundation for universal T-cell based immunotherapy: T cells engineered to express a CD19-specific chimeric-antigen-receptor and eliminate expression of endogenous TCR. Blood 2012; 119 (24): 5697-5705

126. Melenhorst JJ, Leen AM, Bollard CM, Quigley MF, Price DA, Rooney CM, Brenner MK, Barrett AJ, Heslop HE. Allogeneic virus-specific $\mathrm{T}$ cells with HLA alloreactivity do not produce GVHD in human subjects. Blood 2010; 116(22): 4700-4702

127. Kochenderfer JN, Dudley ME, Carpenter RO, Kassim SH, Rose JJ, Telford WG, Hakim FT, Halverson DC, Fowler DH, Hardy NM, Mato AR, Hickstein DD, Gea-Banacloche JC, Pavletic SZ, Sportes C, Maric I, Feldman SA, Hansen BG, Wilder JS, BlacklockSchuver B, Jena B, Bishop MR, Gress RE, Rosenberg SA. Donorderived CD19-targeted $\mathrm{T}$ cells cause regression of malignancy persisting after allogeneic hematopoietic stem cell transplantation. Blood 2013; 122(25): 4129-4139

128. Guo F, Cui J. CAR-T in cancer treatment: develop in selfoptimization, win-win in cooperation. Cancers (Basel) 2021; 13 (8): 1955

129. Hu J, Sun C, Bernatchez C, Xia X, Hwu P, Dotti G, Li S. T-cell homing therapy for reducing regulatory $\mathrm{T}$ cells and preserving 
effector T-cell function in large solid tumors. Clin Cancer Res 2018; 24(12): 2920-2934

130. Murty S, Haile ST, Beinat C, Aalipour A, Alam IS, Murty T, Shaffer TM, Patel CB, Graves EE, Mackall CL, Gambhir SS. Intravital imaging reveals synergistic effect of CAR T-cells and radiation therapy in a preclinical immunocompetent glioblastoma model. OncoImmunology 2020; 9(1): 1757360

131. Grosser R, Cherkassky L, Chintala N, Adusumilli PS. Combination immunotherapy with CAR T cells and checkpoint blockade for the treatment of solid tumors. Cancer Cell 2019; 36(5): 471-482

132. Lee YG, Marks I, Srinivasarao M, Kanduluru AK, Mahalingam SM, Liu X, Chu H, Low PS. Use of a single CAR T cell and several bispecific adapters facilitates eradication of multiple antigenically different solid tumors. Cancer Res 2019; 79(2): 387-396

133. Driouk L, Gicobi JK, Kamihara Y, Rutherford K, Dranoff G, Ritz $\mathrm{J}$, Baumeister SHC. Chimeric antigen receptor $\mathrm{T}$ cells targeting NKG2D-ligands show robust efficacy against acute myeloid leukemia and T-cell acute lymphoblastic leukemia. Front Immunol 2020; 11: 580328

134. Caruana I, Weber G, Ballard BC, Wood MS, Savoldo B, Dotti G. K562-derived whole-cell vaccine enhances antitumor responses of CAR-redirected virus-specific cytotoxic $\mathrm{T}$ lymphocytes in vivo. Clin Cancer Res 2015; 21(13): 2952-2962

135. Bommareddy PK, Shettigar M, Kaufman HL. Integrating oncolytic viruses in combination cancer immunotherapy. Nat Rev Immunol 2018; 18(8): 498-513

136. Hu Z, Ott PA, Wu CJ. Towards personalized, tumour-specific, therapeutic vaccines for cancer. Nat Rev Immunol 2018; 18(3): 168-182

137. Parkhurst MR, Yang JC, Langan RC, Dudley ME, Nathan DA, Feldman SA, Davis JL, Morgan RA, Merino MJ, Sherry RM, Hughes MS, Kammula US, Phan GQ, Lim RM, Wank SA, Restifo NP, Robbins PF, Laurencot CM, Rosenberg SA. T cells targeting carcinoembryonic antigen can mediate regression of metastatic colorectal cancer but induce severe transient colitis. Mol Ther 2011; 19(3): 620-626

138. Blass E, Ott PA. Advances in the development of personalized neoantigen-based therapeutic cancer vaccines. Nat Rev Clin Oncol 2021; 18(4): 215-229

139. Ott PA, Hu Z, Keskin DB, Shukla SA, Sun J, Bozym DJ, Zhang W, Luoma A, Giobbie-Hurder A, Peter L, Chen C, Olive O, Carter TA, Li S, Lieb DJ, Eisenhaure T, Gjini E, Stevens J, Lane WJ, Javeri I, Nellaiappan K, Salazar AM, Daley H, Seaman M, Buchbinder EI, Yoon CH, Harden M, Lennon N, Gabriel S, Rodig SJ, Barouch DH, Aster JC, Getz G, Wucherpfennig K, Neuberg D, Ritz J, Lander ES, Fritsch EF, Hacohen N, Wu CJ. An immunogenic personal neoantigen vaccine for patients with melanoma. Nature 2017; 547(7662): 217-221

140. Hu Z, Leet DE, Allesøe RL, Oliveira G, Li S, Luoma AM, Liu J, Forman J, Huang T, Iorgulescu JB, Holden R, Sarkizova S, Gohil SH, Redd RA, Sun J, Elagina L, Giobbie-Hurder A, Zhang W, Peter L, Ciantra Z, Rodig S, Olive O, Shetty K, Pyrdol J, Uduman M, Lee PC, Bachireddy P, Buchbinder EI, Yoon CH, Neuberg D, Pentelute BL, Hacohen N, Livak KJ, Shukla SA, Olsen LR, Barouch DH, Wucherpfennig KW, Fritsch EF, Keskin DB, Wu CJ, Ott PA. Personal neoantigen vaccines induce persistent memory $\mathrm{T}$ cell responses and epitope spreading in patients with melanoma. Nat Med 2021; 27(3): 515-525
141. Keskin DB, Anandappa AJ, Sun J, Tirosh I, Mathewson ND, Li S, Oliveira G, Giobbie-Hurder A, Felt K, Gjini E, Shukla SA, Hu Z, Li L, Le PM, Allesøe RL, Richman AR, Kowalczyk MS, Abdelrahman S, Geduldig JE, Charbonneau S, Pelton K, Iorgulescu JB, Elagina L, Zhang W, Olive O, McCluskey C, Olsen LR, Stevens J, Lane WJ, Salazar AM, Daley H, Wen PY, Chiocca EA, Harden M, Lennon NJ, Gabriel S, Getz G, Lander ES, Regev A, Ritz J, Neuberg D, Rodig SJ, Ligon KL, Suvà ML, Wucherpfennig KW, Hacohen N, Fritsch EF, Livak KJ, Ott PA, Wu CJ, Reardon DA. Neoantigen vaccine generates intratumoral $\mathrm{T}$ cell responses in phase $\mathrm{Ib}$ glioblastoma trial. Nature 2019; 565 (7738): 234-239

142. Ott PA, Hu-Lieskovan S, Chmielowski B, Govindan R, Naing A, Bhardwaj N, Margolin K, Awad MM, Hellmann MD, Lin JJ, Friedlander T, Bushway ME, Balogh KN, Sciuto TE, Kohler V, Turnbull SJ, Besada R, Curran RR, Trapp B, Scherer J, Poran A, Harjanto D, Barthelme D, Ting YS, Dong JZ, Ware Y, Huang Y, Huang Z, Wanamaker A, Cleary LD, Moles MA, Manson K, Greshock J, Khondker ZS, Fritsch E, Rooney MS, DeMario M, Gaynor RB, Srinivasan L. A phase $\mathrm{Ib}$ trial of personalized neoantigen therapy plus anti-PD-1 in patients with advanced melanoma, non-small cell lung cancer, or bladder cancer. Cell 2020; 183(2): 347-362.e24

143. Lindskog M, Laurell A, Kjellman A, Melichar B, Niezabitowski J, Maroto P, Zieliński H, Villacampa F, Bigot P, Bajory Z.A randomized phase II study with ilixadencel, a cell-based immune primer, plus sunitinib versus sunitinib alone in synchronous metastatic renal cell carcinoma. J Clin Oncol 2020; 38(5_suppl): 11

144. Tanyi JL, Bobisse S, Ophir E, Tuyaerts S, Roberti A, Genolet R, Baumgartner P, Stevenson BJ, Iseli C, Dangaj D, Czerniecki B, Semilietof A, Racle J, Michel A, Xenarios I, Chiang C, Monos DS, Torigian DA, Nisenbaum HL, Michielin O, June CH, Levine BL, Powell DJ Jr, Gfeller D, Mick R, Dafni U, Zoete V, Harari A, Coukos G, Kandalaft LE. Personalized cancer vaccine effectively mobilizes antitumor T cell immunity in ovarian cancer. Sci Transl Med 2018; 10(436): eaao5931

145. Moynihan KD, Opel CF, Szeto GL, Tzeng A, Zhu EF, Engreitz JM, Williams RT, Rakhra K, Zhang MH, Rothschilds AM, Kumari S, Kelly RL, Kwan BH, Abraham W, Hu K, Mehta NK, Kauke MJ, Suh H, Cochran JR, Lauffenburger DA, Wittrup KD, Irvine DJ. Eradication of large established tumors in mice by combination immunotherapy that engages innate and adaptive immune responses. Nat Med 2016; 22(12): 1402-1410

146. Chau I, Haag G, Rahma O, Macarulla T, McCune S, Yardley D, Solomon B, Johnson M, Vidal G, Schmid P, Argiles G, Dimick K, Mahrus S, Abdullah H, He X, Sayyed P, Barak H, Bleul C, Cha E, Drakaki A. MORPHEUS: a phase Ib/II umbrella study platform evaluating the safety and efficacy of multiple cancer immunotherapy (CIT)-based combinations in different tumour types. Ann Oncol 2018; 29(suppl_8): 439-440

147. Simonsen KL, Fracasso PM, Bernstein SH, Wind-Rotolo M, Gupta M, Comprelli A, Reilly TP, Cassidy J. The Fast Real-time Assessment of Combination Therapies in Immuno-ONcology (FRACTION) program: innovative, high-throughput clinical screening of immunotherapies. Eur J Cancer 2018; 103: 259-266

148. Redman JM, Steinberg SM, Gulley JL. Quick efficacy seeking trial (QuEST1): a novel combination immunotherapy study designed 
for rapid clinical signal assessment metastatic castration-resistant prostate cancer. J Immunother Cancer 2018; 6(1): 91

149. Tang J, Shalabi A, Hubbard-Lucey VM. Comprehensive analysis of the clinical immuno-oncology landscape. Ann Oncol 2018; 29 (1): 84-91

150. Monk BJ, Brady MF, Aghajanian C, Lankes HA, Rizack T, Leach J, Fowler JM, Higgins R, Hanjani P, Morgan M, Edwards R, Bradley W, Kolevska T, Foukas P, Swisher EM, Anderson KS, Gottardo R, Bryan JK, Newkirk M, Manjarrez KL, Mannel RS, Hershberg RM, Coukos G. A phase 2, randomized, double-blind, placebo-controlled study of chemo-immunotherapy combination using motolimod with pegylated liposomal doxorubicin in recurrent or persistent ovarian cancer: a Gynecologic Oncology Group partners study. Ann Oncol 2017; 28(5): 996-1004
151. Yu S, Yi M, Qin S, Wu K. Next generation chimeric antigen receptor T cells: safety strategies to overcome toxicity. Mol Cancer 2019; 18(1): 125

152. Levy BP, Giaccone G, Besse B, Felip E, Garassino MC, Domine Gomez M, Garrido P, Piperdi B, Ponce-Aix S, Menezes D, MacBeth KJ, Risueño A, Slepetis R, Wu X, Fandi A, Paz-Ares L. Randomised phase 2 study of pembrolizumab plus CC-486 versus pembrolizumab plus placebo in patients with previously treated advanced non-small cell lung cancer. Eur J Cancer 2019; 108: 120 128

153. Mijalis AJ, Thomas DA 3rd, Simon MD, Adamo A, Beaumont R, Jensen KF, Pentelute BL. A fully automated flow-based approach for accelerated peptide synthesis. Nat Chem Biol 2017; 13(5): 464-466 